
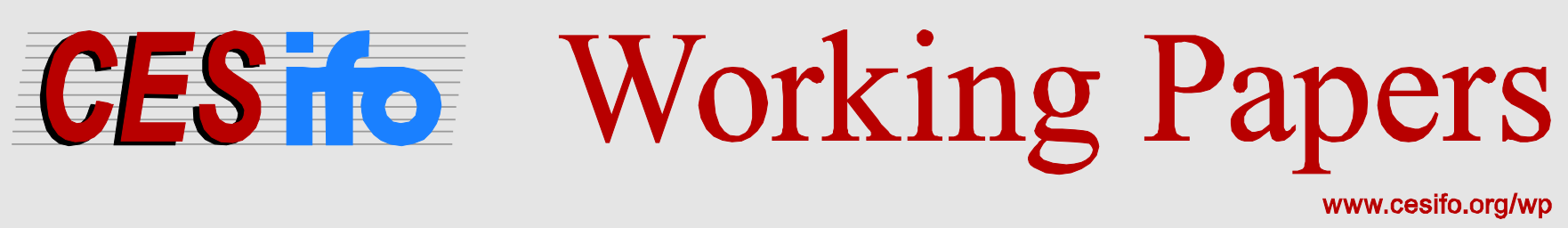

\title{
Integrating India with Asian Production Networks: Prospects and Challenges
}

\author{
Biswajit Nag \\ Biswa Nath Bhattacharyay \\ Debdeep De
}

CESIFO WORKING PAPER NO. 5616

CATEGORY 8: TRADE POLICY

NOVEMBER 2015

An electronic version of the paper may be downloaded

- from the SSRN website:

- from the RePEc website:

- from the CESifo website:

www.SSRN.com

www.RePEc.org

www.CESifo-group.org/wp 


\title{
Integrating India with Asian Production Networks: Prospects and Challenges
}

\begin{abstract}
The formation of regional production networks (RPNs) is one of the most important drivers of growth in East and Southeast Asia. In view of slowdown in growth and even recession in advanced economies as a result of the adverse impact of the global financial crisis of 2008 and the ongoing European debt crisis, RPNs need to reorient their production and exports toward rising middle class of Asia. To successfully implement the new initiative of "Make in India", India needs to be integrated significantly with the RPN. The paper attempts to assess how far intra-industry trade in the form of production and service networks will grow and contribute to the rapid growth in China, India, and Southeast Asian countries, especially from India's perspective. It also examines the trends and patterns; and prospects of integration as well as the prospects for, and the challenges and risks of, significantly integrating India with the RPN. The paper focuses on electronics, automobiles and auto parts and components. The paper finds that in view of high competitiveness in providing outsourced information technology and R\&D services in a wide range of industries, India has tremendous potential to integrate with RPN and become a key player like the PRC. India should improve technological capability, ease of doing business, infrastructure, and local support industries as well as EASE efficient governance and regulatory system, including full transparency in the application of the law.
\end{abstract}

JEL-Codes: F150, F200, L140.

Keywords: Asian regional production network, ASEAN, India, People Republic of China, FTA, manufacturing and service sectors.

\author{
Biswajit Nag \\ Indian Institute of Foreign Trade \\ New Delhi / India \\ biswajit.nag@gmail.com
}

\author{
Biswa Nath Bhattacharyay \\ Asian Development Bank \\ Manila / Philippines \\ dr_biswa@yahoo.com
}

Debdeep De

Jaypee Business School

Noida / India

debdeepde@gmail.com 


\section{Introduction}

One of the most important phenomena in the process of globalization and regionalism is the continued significance of regions as focuses of economic activity where systemic processes of rapid technological change, enhanced capital mobility, and inter-regional competition for investment trigger the regional development. There has been specific focus on inter-firm networks and global value chains which are recognized as key drivers of globalization. Drastic shifts in trade patterns from one-way trade to intra-industry trade have occurred within regions, especially in East and South East Asia. Globalization has given rise to new and more complex trade patterns, particularly trade associated within regional production networks (RPNs). It has been widely recognized that the formation of RPNs has become one of the most important drivers of growth in East and South East Asia. A rapid increase in trade in intermediate goods and parts and components $(P \& C)$ of manufacturing industries provides the clearest evidence for the presence of RPNs in the region. Global value chains and associated production networks are emerging as the organizing framework for production, investment, and trade in an expanding range of product groups such as garments, agro industry, furniture, automobiles and automotive parts, machinery, consumer electronics, telecommunications, and information and communication technology (ICT), as well as various services.

In the mid-1980s, RPNs were developed in East Asia in response to the sharp appreciation of the Japanese yen against the United States (US) dollar. Due to adverse impact of strong yen on price competitiveness, Japanese companies moved their labor-intensive assembly operations to other emerging Asian countries. At first, Japanese firms channelled their investments in the production of intermediate goods to Taipei,China and other newly industrialized economies (NIEs) such as Singapore; Republic of Korea (henceforth, Korea); and Hong Kong, China. However, as the currencies of these economies appreciated, Japanese firms relocated their lower-end labor-intensive assembly to People's Republic of China (PRC) and major economies in the Association of South East Asian Nations (ASEAN). (Thorbeck and Salike, 2011).

Firms in the Asian NIEs also started transferring their factories to developing Asia. This is called the "flying geese" model. Other factors also contributed to the surge in foreign direct investments (FDI) in the region. These include favorable domestic factors in developing South East and East Asian countries such as FDI liberalization, strong macroeconomic fundamentals, and the presence of well-educated low-wage labor, together with favorable external factors such as the US market boom and advances in ICT (Urata 2002). Abundant sources of inputs, proximity of suppliers, managerial organization, and adoption of international standards are the major factors determining investment in RPNs in South East and East Asia (Machikita and Ueki 2010).

As RPNs grew, production and trade in P\&C increased, characterized by vertical specialization in production networks. This has intensified intra-industry trade in $P \& C$, especially in some specific industries such as ICT and electrical machinery (Ando and Kimura 2003). One of the salient features of the expansion of RPN is the spectacular rise of the PRC as the central hub of the production network. East Asian RPNs have played a decisive role in increasing these economies' competitiveness, enabling each of them to climb up the value chain and thus reducing the development gap through raising per capita income within and among countries and generating employment for rural laborers, thereby reducing poverty.

However, while the major East Asian economies joined East Asian RPNs and supply chains linked to international markets for manufactured products and they became a part of the world's production factory, India and other South Asian economies and low-income South East Asian countries have not been able to join existing networks nor established their own 
networks. Despite the potential benefits of India's expanding economy, coupled with a large pool of low-cost and well educated labor, "India has largely been left out of the global division of labor, particularly with regard to the production of parts, components and accessories production" (Rajan and Sen 2002:6). Only in recent times, some attempts by Indian companies are visible to link their production/supply chain with foreign vendors, especially in the automobile sector (Nag 2011). Other sectors such as textile and machinery also have a potential to become part of the Asian RPNs.

In view of the adverse impact of the global financial crisis of 2008 and the ongoing European debt crisis, the advanced economies-Asia's principal export markets-are facing a slowdown in growth and recession. Nowadays, Asian economies need to depend more on intra-regional trade and domestic consumption for sustaining their growth. Deepening, expanding, and integrating Asian production networks to include India and low income ASEAN economies with large middle class markets as well as other major South Asian economies, through India as a gateway, is the need of the day. At the same time, RPNs need to reorient their production and exports toward rising middle class of the PRC, India, and the ASEAN countries (henceforth called $\mathrm{ACl}$ ) ${ }^{1}$ as well as the rest of Asia (Bhattacharyay, 2015).

This paper attempts to understand how far intra-industry trade in the form of production and service network will grow and contribute to the rapid growth in the $\mathrm{ACl}$, especially from India's perspective. It also examines the trends and patterns as well as the prospects, challenges, and risks in significantly integrating India in the Asian production network and in forming India's own network, with a medium-term forward-looking approach until 2030. It focuses on the manufacturing sector in specific industries, such as electronics, automobile and auto component, P\&C, and garment industries, and examines the trends and patterns as well as the prospects, challenges, and risks of India's RPN formation as well as integration in the Asian production networks. Furthermore, it examines the prospect of an Asian services value chain with particular emphasis on service sector integration through free trade agreements (FTAs) and the investment by multinationals from Asia and other regions of the world. The concluding part of the paper provides policy recommendations for integrating Indian manufacturing and service sectors with Asian production networks.

\section{Trends in the Development of Regional Production Network}

Ernst and Kim (2002) described an RPN as a major innovation in the organization of international business, combining concentrated dispersion of a value chain across countries with a parallel process of integrating hierarchical layers of network participants. Global value chains and associated production networks are emerging as the organizing framework for production, investment, and trade in an expanding range of product groups such as garments, agro industry, furniture, automobiles and automotive parts, consumer electronics, telecommunications, and information and communications technology (ICT), as well as various services.

Ernst and Kim (2002) consider that production relations between multinational companies (MNCs) and suppliers have been affected by rapid trade liberalization and an ICT revolution which have helped these firms to become increasingly integrated. Kojima (2000) argues that a shortening of product life cycles is one more reason firms are being forced to fragment their production process, hence locating in different countries. This not only reduces production costs, but at the same time helps firms to launch new products simultaneously in different countries, providing them with quicker access to their consumer base. 
At the beginning of the 1990s, trade in machinery products was dominated by countries such as Germany, Japan, the United Kingdom (UK), and the US. By 2000, however, this had changed, with many developing East Asian countries having become top world traders of such products. A second indication of the presence of RPNs is the growing importance of vertical intra-industry trade.

Athukorala and Yamashita (2006) went further and analyzed in detail the trade in machinery, parts, and components. Kimura and Ando (2004) highlighted the role of Japanese firms in investing in the P\&C sector in East Asia. They argued that parent companies established their foreign affiliates with the objective of conducting a subset of activities that originally were to be undertaken by the parent companies. This is a typical strategy of firms involved in manufacturing operations, which finally leads to both-way trade between parent and affiliates and essentially reflects the existence of product fragmentation. Nag and De (2008), in the context of the car component sector, point out that international production networks, comprising economies like Japan; Korea; Taipei,China; and the PRC work well in East Asia. Gradual integration of the East Asian market with South East Asia is helping these production networks to spread in this sub-region as well. Thailand, Malaysia, and Indonesia already have a large car components sector while other countries like Viet Nam are starting to receive investment in this sector. India and South Asia, however, still outside the regional groupings of East and South East Asian countries, are not as yet in a position to reap the benefits of trade integration.

At World Trade Organization (WTO) talks in 1996, major information technology (IT)producing economies agreed to bind their most-favored nation (MFN) tariffs at zero for specific IT goods, including computers, telecommunications, semiconductors, semiconductor manufacturing equipment, software instruments, and apparatus. Concerning intra-regional trade, three points need to be highlighted. First, Southeast and East Asia (particularly the ASEAN and the PRC) mutually trade P\&C for manufacturing final products within the region. Second, Japan exports the bulk of its products to ASEAN and the PRC, and imports final goods from them. Finally, East Asia's production networks are closely linked with the North American Free Trade Agreement (NAFTA) and the European Union (EU), which export a large portion of their products to ASEAN and the PRC. The PRC and ASEAN economies export mostly consumer goods to these advanced regions. Production networks that exist in the Asian region can be explained by policy factors. First is the tendency of the so-called hollowing out of the Japanese economy in the 1980s that triggered the relocation of the Japanese firms to its neighbouring countries (Baldwin 2007). This hollowing out was motivated by an erosion of competitiveness of the Japanese industries that resulted from an increase in unit labor costs. The rapid growth in wages and incomes in the Japanese economy during the 1980s and 1990s was not compensated by a similar increase in labor productivity. This triggered a policy response, covering both investment and trade, by the economies which had been the target of this industrial relocation. The increased importance of RPNs in East Asia provides the basis for the integration of various Asian economies (De 2011) which is reflected in growing trade in P\&C.

In a recent book by the United Nations Economic and Social Commission for Asia and the Pacific (UNESCAP 2011), the authors argued that RPNs in the region have been driven by increasing trade between economies and that trade liberalization played an important role. However, definitive proof that FTAs have helped the spread of RPNs is lacking. RPNs have been mainly market-driven in Asia, rather than having being driven by trade policy. Regional trade agreements (RTAs) signed by the PRC, Indonesia, and India, for instance, exclude certain industries, in particular automotive, from the agreements or do not provide enough liberalization content. Also, the costs of complying with procedures to obtain preferential tariff 
rates often outweigh the benefits. Instead of creating a more supportive environment for exports, a multitude of RTAs, with varying rules of origin, impede the flow of goods containing inputs from economies outside the RTAs. This is very common in current international production practice. Relatively low tariff rates for manufacturing goods-as a result of unilateral and multilateral liberalization-along with higher administration costs make the negotiated concessions no longer attractive to the business community in the region. Also, the Asia-Pacific Trade Agreement (APTA), the only trade agreement with both the PRC and India as members, is partial in its scope and it fails to foster RPNs between the two countries due to exclusion of P\&C in concessions currently offered by the said agreement. Nevertheless, more positive stories come from the trade agreement between Thailand and India. This agreement has resulted in reduction in trade barriers for specific automotive components, such as gearboxes and parts for spark ignition in engines. This in turn has increased trade in automotive $\mathrm{P} \& \mathrm{C}$ between the two countries.

Table 1: Imports and Tariff Rates of Textile, Car Components, and Electronic Goods, 2007 and 2008

\begin{tabular}{|c|c|c|c|c|c|c|c|c|c|}
\hline \multirow{3}{*}{$\begin{array}{c}\text { Selected } \\
\text { Trade Blocs }\end{array}$} & \multicolumn{3}{|c|}{ Textile } & \multicolumn{3}{|c|}{ Auto components } & \multicolumn{3}{|c|}{ Electronic/integrated Circuits } \\
\hline & $\begin{array}{c}2008 \\
\text { Import } \\
\text { Value }\end{array}$ & $\begin{array}{c}2008 \\
\text { Growth } \\
\text { Rate }\end{array}$ & $\begin{array}{l}2007 \\
\text { Tariff } \\
\text { Rate }\end{array}$ & $\begin{array}{c}2008 \\
\text { Import } \\
\text { Value }\end{array}$ & $\begin{array}{c}2008 \\
\text { Growth } \\
\text { Rate }\end{array}$ & $\begin{array}{l}2007 \\
\text { Tariff } \\
\text { Rate }\end{array}$ & $\begin{array}{c}2008 \\
\text { Import } \\
\text { Value }\end{array}$ & $\begin{array}{c}2008 \\
\text { Growth } \\
\text { Rate }\end{array}$ & $\begin{array}{l}2007 \\
\text { Tariff } \\
\text { Rate }\end{array}$ \\
\hline & (US\$'000) & $(\%)$ & $(\%)$ & (US\$'000) & $(\%)$ & $(\%)$ & (US\$'000) & $(\%)$ & $(\%)$ \\
\hline $\begin{array}{l}\text { ASEAN- } \\
\text { ASEAN }\end{array}$ & $2,545,599$ & 12 & 7.42 & $5,620,119$ & 153 & 8.81 & $21,347,068$ & 4 & 0.95 \\
\hline $\begin{array}{l}\text { ASEAN - } \\
\text { PRC }\end{array}$ & $4,068,580$ & 28 & 11.48 & $1,389,665$ & 148 & 10.17 & $5,330,720$ & 107 & 0.79 \\
\hline $\begin{array}{l}\text { ASEAN - } \\
\text { India }\end{array}$ & 603,339 & 57 & 12.63 & 200,089 & 197 & 12.5 & 21,081 & 130 & 2.5 \\
\hline $\begin{array}{l}\text { ASEAN - } \\
\text { SAARC }\end{array}$ & 832,663 & 25 & 14.24 & 202,871 & 187 & 16.18 & 25,130 & 153 & 5.4 \\
\hline $\begin{array}{l}\text { ASEAN - } \\
\text { Singapore }\end{array}$ & 235,932 & 83 & 7.42 & 608,398 & 165 & 8.81 & $4,956,510$ & 13 & 0.95 \\
\hline $\begin{array}{l}\text { ASEAN - } \\
\text { Thailand }\end{array}$ & 486,809 & 2 & 7.42 & $2,749,917$ & 183 & 8.81 & $1,834,902$ & 14 & 0.95 \\
\hline $\begin{array}{l}\text { PRC - } \\
\text { India }\end{array}$ & $1,375,429$ & 200 & 12.69 & 57,524 & 59 & 12.50 & 34,300 & 305 & 2.5 \\
\hline $\begin{array}{l}\text { India - } \\
\text { Thailand }\end{array}$ & 107,377 & 68 & 21.29 & 279,669 & 290 & 14.34 & 5,195 & -43 & 2.5 \\
\hline $\begin{array}{l}\text { Japan - } \\
\text { Singapore }\end{array}$ & 2,523 & -61 & 6.86 & 24,086 & 19 & 0.39 & $1,303,362$ & 15 & 0 \\
\hline
\end{tabular}

Notes: ASEAN= Association of Southeast Asian Nations; PRC= People's Republic of China.

SAARC: South Asian Association for Regional Cooperation

Source: Nag and De 2011

Although India and Korea are already part of the APTA, the RTA between the two countries has gone beyond tariff concessions of trade in the goods outlined in APTA. Apart from tariff concessions, the RTA—-known as the India-Korea Comprehensive Economic Partnership Agreement (IKCEPA) - also includes trade in services, intellectual property rights, measures of trade facilitation, and investment liberalization. Kumar (2007) found that soon after the start of negotiations, Tata Motors of India acquired Daewoo Motors of Korea in 2005, and begun an RPN strategy for producing small and medium-sized cars. This business strategy was implemented in order to gain early advantage when the RTA entered into force on 1 
January 2010. In particular, IKCEPA includes the promotion of cooperation, either through investment and/or tariff reductions, in several sectors including the automotive sector.

\section{Barriers to Entry of International Firms: Insights From a Survey of Japanese Investors}

A 2010 survey of Japanese manufacturers' foreign investment plans for the next three years by the Japan Bank for International Cooperation $(\mathrm{JBIC})^{2}$ revealed valuable insights on barriers to entry of foreign investments. In the said survey, while the PRC has remained the overwhelming primary destination of FDI by Japanese manufacturers in the past 10 years, India has been observed to be gaining fast (Figure 1).

Figure 1: Promising FDI Host Countries for Surveyed Japanese Firms, $\quad \mathbf{2 0 0 0 - 2 0 1 0 ~ ( \% ~}$ of response)

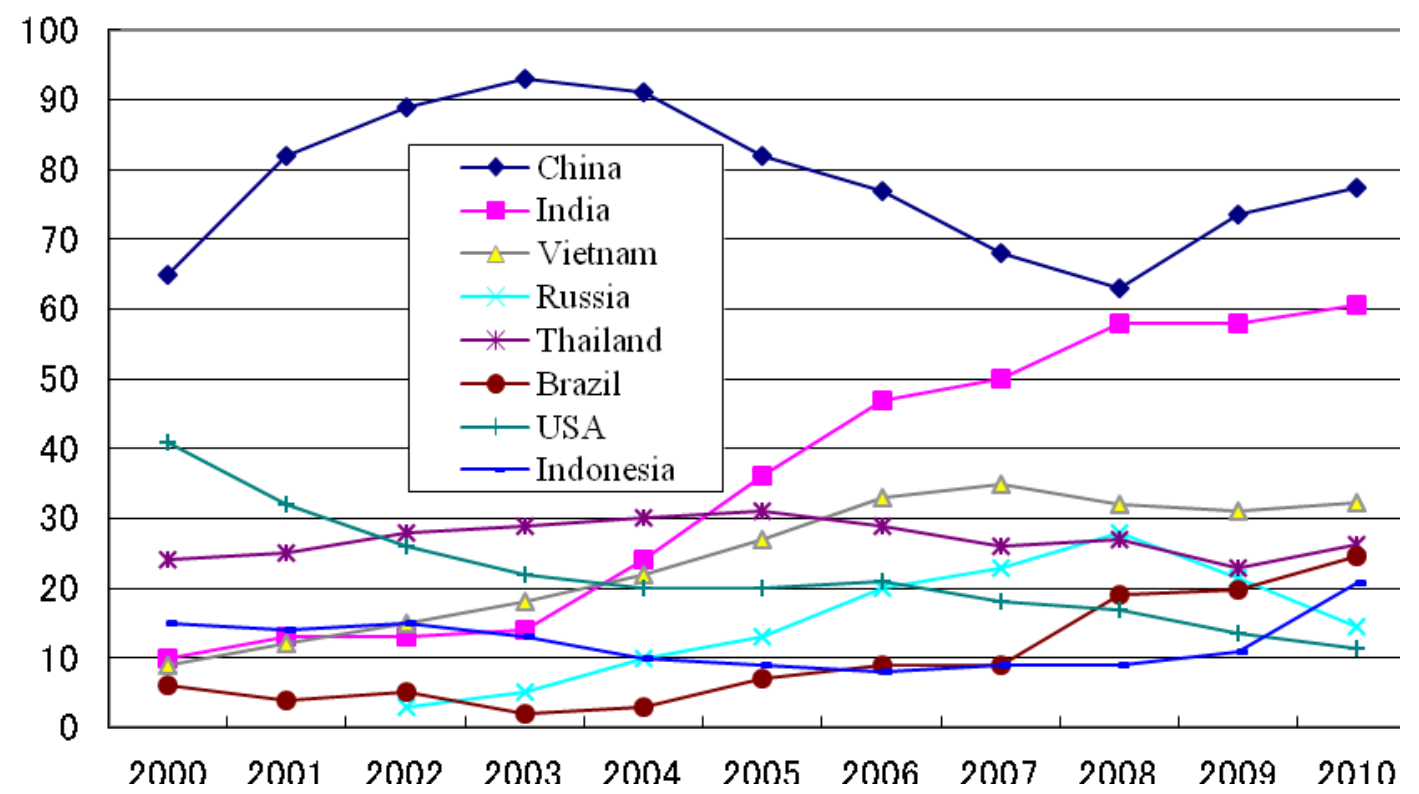

Source: Japan Bank for International Cooperation (JBIC)

According to the JBIC survey, the most important motive for Japanese FDI in Asiaespecially in the PRC and India-is sales in host markets. The next major considerations in many Asian countries are availability of low-wage labor and supply bases for assemblers. These observations suggest that many Japanese parts suppliers are expanding their business with Japanese assemblers in these countries.

However, Japanese investors do not consider India as an attractive export platform. This indicates that Japanese firms may not be planning to include India in regional production networks in the near future. Also, industrial clusters or agglomeration is not a relatively significant factor in influencing Japanese FDI in India, compared with that in the PRC and certain ASEAN countries. These are in contrast with strategies of Korean companies like

\footnotetext{
${ }^{2} \mathrm{JBIC}$ has been conducting a questionnaire survey on overseas operation of Japanese manufacturing firms annually since 1989. For the 2010 survey (JBIC, 2010), a questionnaire was sent in July 2010 to 961 Japanese manufacturing firms with at least three overseas affiliates by post. JBIC received responses from 605 firms, and thus the response rate was 63 percent.
} 
Hyundai, which export vehicles from India. Moreover, based on the studies conducted by Nag (2011), India has a promising export opportunities in the automobile sector, particularly for markets in Europe and Africa.

Meanwhile, the survey also revealed a number of problems that Japanese firms face in conducting business in these countries. Tough domestic competition is one problem (Table 2 ), albeit that this benefits the host economies. Another is the lack of transparency in the application of the law, which is considered a more serious problem for Japanese firms' operations. This problem is particularly acute in the PRC and rather serious in India, Viet Nam, and Indonesia. Other sets of problems apply to specific countries like underdeveloped infrastructure which are the top concerns in India and Viet Nam.

Table 2: Problems Faced by Surveyed Japanese Firms

\begin{tabular}{|c|c|c|c|c|c|c|c|c|}
\hline \multicolumn{9}{|c|}{ in Selected Asian Countries, 2010} \\
\hline $\begin{array}{l}\text { JBIC Survey } \\
\text { Ranking }\end{array}$ & 1 & 2 & 3 & 4 & 6 & 9 & 10 & 10 \\
\hline Country & PRC & India & $\begin{array}{l}\text { Viet } \\
\text { Nam }\end{array}$ & Thailand & Indonesia & Korea & $\begin{array}{l}\text { Taipei, } \\
\text { China }\end{array}$ & Malaysia \\
\hline \# of respondents & 377 & 294 & 156 & 128 & 98 & 30 & 28 & 25 \\
\hline $\begin{array}{l}\text { Underdeveloped } \\
\text { legal system }\end{array}$ & 15.1 & 18.7 & 19.2 & 5.5 & 11.2 & - & 0.0 & - \\
\hline $\begin{array}{l}\text { Lack of } \\
\text { transparency in } \\
\text { legal matters }\end{array}$ & 57.8 & 26.9 & 24.4 & 8.6 & 22.4 & 3.3 & 3.6 & - \\
\hline $\begin{array}{l}\text { Complicated tax } \\
\text { system }\end{array}$ & 12.7 & 24.5 & 4.5 & 5.5 & 4.1 & - & - & - \\
\hline $\begin{array}{l}\text { Lack of } \\
\text { transparency in } \\
\text { tax treatment }\end{array}$ & 31.8 & 16.3 & 11.5 & 6.3 & 10.2 & 3.3 & 7.1 & - \\
\hline Heavy taxes & 22.0 & 5.4 & 2.6 & 4.7 & 5.1 & 10.0 & - & 12.0 \\
\hline FDI restriction & 27.3 & 11.9 & 12.8 & 7.0 & 7.1 & - & - & 12.0 \\
\hline $\begin{array}{l}\text { Complicated/non- } \\
\text { transparent FDI } \\
\text { screening }\end{array}$ & 25.2 & 15.6 & 9.0 & 3.1 & 6.1 & - & 3.6 & - \\
\hline $\begin{array}{l}\text { Insufficient IPR } \\
\text { protection }\end{array}$ & 50.7 & 8.2 & 6.4 & 4.7 & 8.2 & 3.3 & - & 8.0 \\
\hline $\begin{array}{l}\text { Restriction on } \\
\text { foreign exchange } \\
\text { dealings }\end{array}$ & 33.7 & 9.2 & 7.7 & 3.1 & 3.1 & 6.7 & 3.6 & - \\
\hline $\begin{array}{l}\text { Import } \\
\text { restriction/Proble } \\
\text { matic customs }\end{array}$ & 18.8 & 11.6 & 9.0 & 5.5 & 8.2 & 6.7 & 7.1 & - \\
\hline
\end{tabular}




\begin{tabular}{|c|c|c|c|c|c|c|c|c|}
\hline procedures & & & & & & & & \\
\hline $\begin{array}{l}\text { Difficulty in } \\
\text { recruiting } \\
\text { engineers }\end{array}$ & 17.5 & 9.5 & 17.3 & 21.9 & 16.3 & 3.3 & 7.1 & 24.0 \\
\hline $\begin{array}{l}\text { Difficulty in } \\
\text { recruiting middle } \\
\text { management }\end{array}$ & 25.5 & 17.7 & 26.3 & 30.5 & 18.4 & 10.0 & 14.3 & 32.0 \\
\hline Rising wages & 63.7 & 17.3 & 21.2 & 25.0 & 18.4 & 20.0 & 17.9 & 20.0 \\
\hline Labor relations & 36.1 & 16.0 & 9.0 & 11.7 & 11.2 & 10.0 & - & 8.0 \\
\hline $\begin{array}{l}\text { Tough } \\
\text { competition with } \\
\text { other firms }\end{array}$ & 56.5 & 31.6 & 19.9 & 32.8 & 25.5 & 66.7 & 57.1 & 28.0 \\
\hline $\begin{array}{l}\text { Difficulty in } \\
\text { collecting } \\
\text { payment }\end{array}$ & 31.3 & 8.5 & 3.2 & 1.6 & 4.1 & - & 3.6 & - \\
\hline $\begin{array}{l}\text { Difficulty in } \\
\text { obtaining finance }\end{array}$ & 5.8 & 6.1 & 3.8 & 0.8 & 2.0 & - & - & 4.0 \\
\hline $\begin{array}{l}\text { Underdeveloped } \\
\text { local supporting } \\
\text { industry }\end{array}$ & 5.8 & 12.2 & 16.0 & 3.1 & 7.1 & - & - & - \\
\hline $\begin{array}{l}\text { Unstable } \\
\text { exchange } \\
\text { rate/prices }\end{array}$ & 4.5 & 4.1 & 9.0 & 1.6 & 10.2 & 6.7 & - & - \\
\hline $\begin{array}{l}\text { Underdeveloped } \\
\text { infrastructure }\end{array}$ & 11.9 & 47.6 & 30.8 & 7.0 & 17.3 & - & - & 4.0 \\
\hline $\begin{array}{l}\text { Insecure social } \\
\text { environment }\end{array}$ & 10.1 & 19.0 & 3.2 & 50.0 & 28.6 & 6.7 & 3.6 & 4.0 \\
\hline $\begin{array}{l}\text { Lack of } \\
\text { information on } \\
\text { FDI host }\end{array}$ & 1.6 & 20.4 & 14.1 & 3.9 & 8.2 & 6.7 & - & 4.0 \\
\hline \multicolumn{9}{|c|}{$\begin{array}{l}\text { The proportional shares of responding firms indicating the motive in total numb } \\
\text { Three items receiving three highest proportions for each country are shaded. } \\
\text { Source: JBIC (2010) }\end{array}$} \\
\hline
\end{tabular}

Rapid integration of India into the RPNs could be a major opportunity for expanding production networks across Asia. There are signs that India is becoming a growing source of automobile and electronic components for products assembled in East Asian countries and for export to Europe and the Middle East. India's imports of electric machinery and 
transportation machinery $P \& C$ from East Asia have increased more than six-fold and ninefold, respectively, from 2000 to 2009 , while the country's exports went up by 11 -fold for final electric machinery products and by nearly 10 -fold for transportation machinery. ${ }^{3}$ The involvement of India in RPNs will increase if it can successfully attract FDI and develop its manufacturing base. India also needs to improve its skill-base and technological capability. Given the country's competitiveness in providing outsourced information technology and R\&D services in a wide range of industries, India has enormous potential.

\section{Regional Production Network in Manufacturing and India's Trade}

Many companies, particularly smaller enterprises, are finding that success and value creation may be achieved through specialization in a limited set of activities, outputs, and market niches. However, in order to participate in such value chains and networks, firms must be able to deliver a specified product, in the right quantity, with the required quality, and at the right time while meeting an expanding range of increasingly stringent global market standards like labor conditions and environment concerns, to name a few. Japanese investment in the early years initiated the process. Later, several small and medium enterprises (SMEs) moved up the value chain through improving process capability and product upgrading.

Ando and Kimura (2003) concluded that the most important change in the trade pattern of the region was the explosive increase in the trading of machinery $P \& C$, including general machinery, electrical machinery, transport equipment, and precision machinery. In this context the present study focuses on a few major industries-electronics, P\&C, textiles, and car components associated with the formation of RPNs and their interlinkages, in the Indian context, with different nations in Asia.

\subsection{Electronics Industry}

The electronics industry takes top position, especially in Asia, in terms of forming RPNs. Promoted by Japanese companies at the initial stage, the industry has reached maturity in East Asian economies such as Taipei,China and the PRC. Gradually it has spread into South East Asia, into economies such as in Thailand and Malaysia. The large number of component manufacturers across the region are specializing in several areas such as microprocessors, printed circuits, telecoms and computer parts, resistors, capacitors, inductors, crystals, resonators, speakers, audio-visual (AV) equipment, consisting of radios and optical discs players, hi-fi equipment, TV sets, and MP3/MP4 players, among others. ${ }^{4}$ As India is a major market for the electronics industry, it is interesting to observe how Asian economies are performing in these industries. It is also worth noting that India's electronics industry has been evolving very fast and it is now a consistent supplier of several commodities to the world. Solectron, Flextronics, Jabil Circuits, Samtel, Moser Baer, Hical Magnetics, and Midas Communication, among others are some of India's most promising companies.

\footnotetext{
${ }^{3}$ Computed from the RIETI trade database.

${ }^{4}$ To analyze the trade data, we have considered several product categories in the electronics industry comprising items falling in Chapter 85 of HS codes and HS 8415, HS 8418, HS 8471, and HS 8473.
} 


\subsubsection{Exports}

The export volume of the electronics industry in India was US\$7.6 billion in 2010-2011, more than four times compared with US\$ 1.57 billion in 1999-2000. In terms of exports by type of electronic products, most exports of the electronics industry in India are in the form of electronic components, followed by industrial electronics, and computers (US\$273 million). In general, a rising trend has recently been observed in electronics exports, but with some exceptions (Appendix 1). In 2009, the primary export partner of India for its electronics products was the US, followed by Singapore; United Arab Emirates (UAE); Germany; and Hong Kong, China (Table 3). The composition of exports markets indicates that while India primarily supplies to Western countries, it is slowly getting linked with Asian partners.

Table 3: Major Destinations of India's Electronic Exports, 2009

\begin{tabular}{|l|r|}
\hline \multicolumn{1}{|c|}{ Country Name } & \multicolumn{1}{c|}{$\begin{array}{c}\text { Value } \\
\text { (US\$ Million) }\end{array}$} \\
\hline United States & 809.23 \\
\hline Singapore & 452.15 \\
\hline $\begin{array}{l}\text { United Arab } \\
\text { Emirates }\end{array}$ & 449.83 \\
\hline Germany & 369.31 \\
\hline Hong Kong, China & 317.66 \\
\hline Netherlands & 270.66 \\
\hline PRC & 256.11 \\
\hline Indonesia & 189.29 \\
\hline Nigeria & 157.04 \\
\hline Romania & 154.30 \\
\hline Others & 2033.94 \\
\hline Total & 5459.53 \\
\hline
\end{tabular} Source: World Integrated Trade Solution (WITS) (Accessed December 22, 2011)

\subsubsection{Imports}

Total imports of the electronics industry in India reached US\$18.17 billion in 2010-11, more than four (4)-fold of US\$ 4.19 billion in 1999-2000. About $21 \%$ of the electronics imports of India were used as input for the consumer electronics segment. This indicates that intraindustry trade in intermediate products in the electronics industry of India is becoming visible. Table 4 exhibits major sources of India's electronic imports by countries. Table 5 presents volume of imports of electronic products by major category during 2006-2011. For instance, imports of audio-visual electronics parts and accessories (HS 8523) and telecom equipment (HS 8517) have increased substantially in the recent past (Table 5). 
Table 4: Major Sources of India's Electronic Imports, 2009

\begin{tabular}{|l|r|}
\hline Country Name & \multicolumn{2}{|c|}{$\begin{array}{c}\text { Value } \\
\text { (US\$ Million) }\end{array}$} \\
\hline PRC & 12178.47 \\
\hline Singapore & 1933.71 \\
\hline United States & 1558.66 \\
\hline Germany & 1471.64 \\
\hline Korea & 1359.58 \\
\hline Japan & 1224.75 \\
\hline Malaysia & 883.86 \\
\hline $\begin{array}{l}\text { Hong Kong, } \\
\text { China }\end{array}$ & 859.12 \\
\hline Sweden & 744.36 \\
\hline Finland & 732.15 \\
\hline
\end{tabular}

Source: WITS (Accessed December 22, 2011)

Most of the electronics imports of India in 2009 came from the PRC; Singapore; Korea; Japan; Malaysia; and Hong Kong, China. The PRC, Singapore, and US were India's top three import partners (Table 4). This implies that India is already a major market for products originating in Asia, but as discussed previously, it has also started exporting to these countries.

Table 5: Imports of Indian Electronics Industry (Values in US\$ Million)

\begin{tabular}{|c|c|c|c|c|c|c|}
\hline HS & Commodity/Product & 2006-2007 & $\begin{array}{l}2007- \\
2008\end{array}$ & $\begin{array}{l}2008- \\
2009\end{array}$ & $\begin{array}{l}2009- \\
2010\end{array}$ & $\begin{array}{l}2010- \\
2011\end{array}$ \\
\hline 8501 & $\begin{array}{l}\text { Elctrc Motrs \& Genrtrs(Excl Genrtng } \\
\text { Sets) }\end{array}$ & 244.92 & 421.93 & 452.93 & 441.67 & 464.85 \\
\hline 8502 & $\begin{array}{l}\text { Electrc Genrtng Sets } \& \quad \text { Rotary } \\
\text { Convrtrs }\end{array}$ & 114.21 & 359.99 & 192.82 & 183.65 & 166.3 \\
\hline 8503 & $\begin{array}{l}\text { Parts Sutbl Fr Use Solely/Prncplly } \\
\text { With Themchns Of Hdg No.8501 And } \\
8502\end{array}$ & 427.02 & 415 & 435.82 & 364.19 & 382.58 \\
\hline 8504 & $\begin{array}{l}\text { Electrcl Transformers, Static Cnvrtrs } \\
\text { (For Example, Rectifiers)\& Inductors }\end{array}$ & 558.3 & 869.5 & $1,124.71$ & 997.18 & 819.28 \\
\hline 8505 & $\begin{array}{l}\text { Elctro-Mgnt; Prmnent Mgnts \& Artcls } \\
\text { To Makeprmnent Mgnt;Elctro } \\
\text { Mgntc/Prmnent Devics Elctro Mgntc } \\
\text { Cltchs,Brks \& Lftng Hds }\end{array}$ & 60.71 & 63.23 & 71.02 & 67.55 & 83.87 \\
\hline 8506 & Primary Cells \& Primary Batteries & 65.83 & 66.42 & 419.55 & 203.36 & 80.48 \\
\hline 8507 & $\begin{array}{l}\text { Elctrc } \quad \text { Accumltrs,Incl } \quad \text { Separators } \\
\text { Therefore W/N Rectangular(Incl Sq) }\end{array}$ & 173.73 & 385.77 & 366.5 & 275.7 & 240.62 \\
\hline 8509 & $\begin{array}{l}\text { Elctro-Mechncl Domestic Appliances } \\
\text { With Self-Contained Elctrc Motor }\end{array}$ & 11.02 & 19.22 & 7.25 & 9.51 & 9.44 \\
\hline 8510 & $\begin{array}{l}\text { Shavers,Hairclippers \& Hair-Removng } \\
\text { Appliancs,Wth Self-Containd Elctric } \\
\text { Motor. }\end{array}$ & 1.16 & 2.21 & 2.43 & 3.03 & 5.04 \\
\hline
\end{tabular}




\begin{tabular}{|c|c|c|c|c|c|c|}
\hline 8511 & $\begin{array}{l}\text { Elctrcl Igntn/Strtng Eqpmnt Fr Sprk- } \\
\text { Igntn Etc Gnrtrs Etc \& Cut Outs Of A } \\
\text { Kind Used In Conjunction Wth Such } \\
\text { Engines }\end{array}$ & 76.31 & 78.13 & 137.36 & 160.96 & 118.14 \\
\hline 8512 & $\begin{array}{l}\text { Elecrcl Ligtng/Signalling Eqpmnt (Excl } \\
\text { Articles Of Hd No.8539)Wind Scrn Etc } \\
\text { Used For Cycles/Motor Vehicles }\end{array}$ & 45.54 & 58.43 & 64.42 & 64.66 & 69.22 \\
\hline 8513 & $\begin{array}{l}\text { Portable Elctrc Lamps Designed To } \\
\text { Function By Their Own Source Of } \\
\text { Energy Other Than Lighting } \\
\text { Equipments Of Hdg No.8512 }\end{array}$ & 8.42 & 10.39 & 13.3 & 32.59 & 20.16 \\
\hline 8514 & $\begin{array}{l}\text { Indstr//Laboratory Elctrc (Including } \\
\text { Inductn/ Dielctrc)Furnaces Etc;Othr } \\
\text { Indstrl/ Laboratory Inductn/Dielctrc } \\
\text { Htng Eqpmnts }\end{array}$ & 49.52 & 77.79 & 102.73 & 74.99 & 67.19 \\
\hline 8515 & $\begin{array}{l}\text { Elctr(Incl Elctaclly Htd Gas)Laser/Othr } \\
\text { Light/Photon Beam Etc,Brzng/Sldrng } \\
\text { Mchns Etc Fr Hot Spryng Of } \\
\text { Mtls/Cermets }\end{array}$ & 118.37 & 189.81 & 229.31 & 170.27 & 121.06 \\
\hline 8516 & $\begin{array}{l}\text { Elctrc Wtr \& Imrsn Htr ; Elctrc Spaces } \\
\& \text { Htng Aprts;Elctro Thrmic Hair } \\
\text { Drssng Aprts\&Hnd Dryrs;Smlr Elctrc } \\
\text { Aplncs Fr Dmstc Use }\end{array}$ & 90.11 & 110.55 & 118.76 & 139.67 & 155.26 \\
\hline 8517 & $\begin{array}{l}\text { Elctrcl Aparts Fr Line } \\
\text { Telephny/Telgrphy, Incl Telphon Sets } \\
\text { Wth Cordls Handset Carier-Curent } \\
\text { Line Systm; Videophone }\end{array}$ & $1,952.21$ & $4,310.30$ & $8,960.91$ & $8,335.89$ & $7,065.96$ \\
\hline 8518 & $\begin{array}{lr}\text { Mcrophones\&Stnds } & \\
\text { Thrfr;Loudspkr,W/N } & \text { Mntd } \\
\text { Headphone,Earphone \& } & \text { Combnd } \\
\text { Mcrophone/Spkrsets;Audio } & \text { Frqncy } \\
\text { Amplfyr;Snd Amplfyr Sets } & \end{array}$ & 132.64 & 183.16 & 297.39 & 238.12 & 204.09 \\
\hline 8519 & $\begin{array}{l}\text { Turntables } \\
\text { (Recorddecks)Record- } \\
\text { Players Cassette Players Etc Nt } \\
\text { Incorporating A Sound Recording } \\
\text { Device }\end{array}$ & 49.19 & 67.97 & 98.82 & 108.86 & 77.91 \\
\hline 8521 & Video Recording/Reproducing Apprts & 73.44 & 105.63 & 117.12 & 119.29 & 94.6 \\
\hline 8522 & $\begin{array}{l}\text { Prts \& Acssrs Of Apprts Of Hdgs Nos. } \\
8519 \text { To } 8521\end{array}$ & 89.87 & 89.89 & 113.15 & 93.21 & 85.14 \\
\hline 8523 & $\begin{array}{l}\text { Preprd Unrecorded Media For Sound } \\
\text { Recrdng/Smlr Recrdng Of Othr } \\
\text { Phenomena,Othr Thn Prdcts Of Ch.37 }\end{array}$ & 100.78 & 222.64 & $1,817.81$ & $2,107.99$ & 882.08 \\
\hline 8525 & $\begin{array}{l}\text { Trnsmisn Aparats Fr Radio,Telephny } \\
\text { Etc W/N Incrprtng Reception } \\
\text { Apprts/Sound Recording/Reprdcng } \\
\text { Apprts;Tv Cameras Etc }\end{array}$ & $4,105.14$ & $4,064.39$ & 868.97 & 359.35 & 276.42 \\
\hline
\end{tabular}




\begin{tabular}{|c|c|c|c|c|c|c|}
\hline 8526 & $\begin{array}{l}\text { Radar Aparats,Radio Navigational Aid } \\
\text { Apparatus \& Radio Remote Control } \\
\text { Aparats }\end{array}$ & 33.35 & 124.8 & 67.34 & 36.38 & 31.13 \\
\hline 8527 & $\begin{array}{l}\text { Reception Apprts Fr Radio Telephony } \\
\text { Etc W/N Cmbnd,In The Same } \\
\text { Housing, } \quad \text { Wth } \\
\text { Recording/Reprdcng Apprts/A Clock }\end{array}$ & 72.8 & 83.49 & 121.49 & 25.06 & 59.64 \\
\hline 8528 & $\begin{array}{lr}\text { Reception } & \text { Aparatus,Wh/Not } \\
\text { Incorprtng } & \text { Radiobrodcst } \\
\text { Recivrs/Sound/Video } & \text { Rcordng/ } \\
\text { Reproducing Aparatus, Video Monitors } \\
\text { Etc }\end{array}$ & 344.67 & 703.6 & $1,064.42$ & 971.23 & 915.53 \\
\hline 8529 & $\begin{array}{l}\text { Prts Suitbl Fr Use Solely/Prncplly Wth } \\
\text { Apprts Of Hdgs Nos } 8525 \text { To } 8528\end{array}$ & 810.7 & 796.04 & $1,054.18$ & 800.51 & 657.1 \\
\hline 8530 & 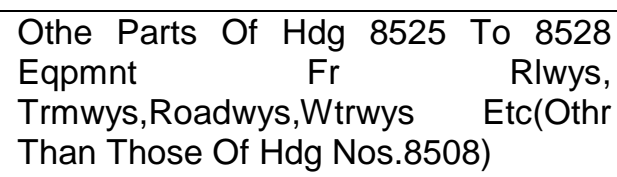 & 20.59 & 32.12 & 37.5 & 46.94 & 10.75 \\
\hline 8531 & $\begin{array}{l}\text { Elctrc } \quad \text { Sound/Visual } \quad \text { Signllng } \\
\text { Apprts(E.G. Bells Sirens Etc.)Othr Thn } \\
\text { Those Of Hdg No.8512/8530 }\end{array}$ & 73.52 & 86.57 & 99.41 & 145.77 & 91.89 \\
\hline 8532 & $\begin{array}{lcl}\text { Elctrcl } & \text { Capacitors } & \text { Fixd,Variable/ } \\
\text { Adjustable(Pre-Set) } & \end{array}$ & 135.25 & 153.31 & 375.82 & 224.6 & 180.58 \\
\hline 8533 & $\begin{array}{ll}\text { Elctrcl Resistors(Incl } & \text { Rheostats \& } \\
\text { Potentiometers)Othr Thn Htng } \\
\text { Resistors }\end{array}$ & 64.9 & 78.16 & 107.83 & 109.62 & 68.99 \\
\hline 8534 & Printed Circuits & 76.91 & 76.98 & 296.16 & 155.72 & 95.88 \\
\hline 8535 & $\begin{array}{l}\text { Elctrcl Apprts Fr Swtchng/Protctng } \\
\text { Elctrclcircuits } \\
\text { Swtchs,Fuses,Lightning } \quad \text { Etc.(E.G. Arresters } \\
\text { Etc)Fr A Vltg Excdg } 1000 \text { Volts }\end{array}$ & 50.95 & 68.6 & 107.02 & 142.9 & 128.79 \\
\hline 8536 & $\begin{array}{l}\text { Elctrcls Apprts Fr Swtchng/Prtctng } \\
\text { Elctrclcircuits Etc.(E.G.Swtchs Relays } \\
\text { Etc.) For A Voltage Not Excdg } 1000 \\
\text { Volts }\end{array}$ & 462.3 & 584.6 & 816.63 & 693.98 & 549.45 \\
\hline 8537 & $\begin{array}{l}\text { Bords Panls Etc Equipd Wth Two Or } \\
\text { More Apprts Of Hdg } 8535 / 8536 \text {,Incl } \\
\text { Those Incorprtng Instrmnts/Apprts Of } \\
\text { Ch } 90\end{array}$ & 128.31 & 211.53 & 218.95 & 198.64 & 165.51 \\
\hline 8538 & $\begin{array}{l}\text { Prts Suitbl Fr Use Solely/Principally } \\
\text { Wth The Apprts Of Hdg } \\
\text { No.8535,8536/8537 }\end{array}$ & 406.45 & 530.71 & 553.16 & 518.33 & 412.29 \\
\hline 8539 & $\begin{array}{l}\text { Electric Filmnt/Discharge Lamps,Incl } \\
\text { Beam Lamp Units \& U-V/Infra-Red } \\
\text { Lamps Etc. }\end{array}$ & 124.92 & 147.92 & 153.6 & 141.46 & 124.93 \\
\hline
\end{tabular}




\begin{tabular}{|c|c|c|c|c|c|c|}
\hline 8540 & $\begin{array}{l}\text { Thermionic Cold Cathode/Photo- } \\
\text { Cathode \&alves \& } \\
\text { Tubes(E.G.Vacuum/Vapour/Gas Filled } \\
\text { Valves Tubes Etc.) }\end{array}$ & 167.96 & 202.07 & 207.83 & 217.94 & 229.06 \\
\hline 8541 & $\begin{array}{l}\text { Diodes,Transistors \& Smlr Semi- } \\
\text { Conductors Devices Etc.W/N Assmbld } \\
\text { In Modules/Made Up Into Pnls Etc } \\
\text { Mntd Piezo-Elctrc Crystls }\end{array}$ & 359.95 & 474.61 & 923.34 & 667.93 & 465.73 \\
\hline 8542 & $\begin{array}{l}\text { Elctrnc Integrtd Circuits \& Micro- } \\
\text { Assmbls }\end{array}$ & 670.69 & 728.86 & $1,246.96$ & $1,036.50$ & 693.41 \\
\hline 8543 & $\begin{array}{l}\text { Elctrcl Mchns \& } \text { Apprts, } \text { Having } \\
\text { Individual Fnctns N.E.S. In This } \\
\text { Chapter }\end{array}$ & 310.18 & 436.42 & 567.59 & 385.05 & 354.78 \\
\hline 8544 & $\begin{array}{l}\text { Insulated(Incl Enmlld/Anodise)Wire } \\
\text { Etc. Optcl Fbre Cables W/N Fitted } \\
\text { Wth Cnnctrs/ Assembled With Electric } \\
\text { Conductors }\end{array}$ & 488.34 & 921.81 & 871.86 & 689.54 & 532.99 \\
\hline 8545 & $\begin{array}{l}\text { Crbn Elctrds,Crbn Brshs,Lamp Crbns } \\
\text { Etc. Othr Artcls Of Graphite/Othr } \\
\text { Crbn,Wth/ Wthout Mtl Of A Knd Used } \\
\text { For Elctrcl Purps }\end{array}$ & 64.48 & 88.96 & 131.09 & 151.04 & 135.18 \\
\hline 8546 & Electrical Insulators Of Any Material & 28.49 & 46.15 & 61.63 & 67.56 & 62.1 \\
\hline 8547 & $\begin{array}{l}\text { Insltng Fttngs Fr Elctrcl Mchns Etc. } \\
\text { Electrcl Conduit Tubing \& Joints } \\
\text { Therof Ofbse Mtl Lined Wth Insulating } \\
\text { Matrl }\end{array}$ & 32.44 & 57.6 & 70.64 & 73.62 & 63.98 \\
\hline 8548 & $\begin{array}{l}\text { Wast \& Scrap Of Primary Cells,Batrs } \\
\& \text { Electrc Acumultrs; Spent Prmry } \\
\text { Cels, Batrselctrc Acumultrs, Elctrcl } \\
\text { Prts Of Machinery }\end{array}$ & 14.68 & 15.75 & 26.55 & 11.24 & 7.19 \\
\hline 8415 & $\begin{array}{l}\text { Aircondtng Mchns,Cmprsng Motr-Drvn } \\
\text { Fan \& Elmnts Fr Chng Tmprtr \& } \\
\text { Humdty ,Incl Thosemchns In Whch } \\
\text { Humdty Cannt Be Sprtly Rgltd }\end{array}$ & 283.69 & 450.67 & 389.2 & 63.68 & 45.77 \\
\hline 8418 & $\begin{array}{l}\text { Rfrgrtrs,Frzrs \& Othr Rfrgrtng/Frzng } \\
\text { Eqpmnt,Elctrc/Othr;Ht Pumps Excl Air } \\
\text { Condtng Mchns Of Hdg No.8415 }\end{array}$ & 176.29 & 214.71 & 256.63 & 167.97 & 114.06 \\
\hline 8471 & $\begin{array}{l}\text { Automtc Data Prcsng Mchns \& } \\
\text { Units;Mgntc/ Optcl Readrs,Mchns Fr } \\
\text { Trnscrbng Data Onto Data Media In } \\
\text { Coded Form N.E.S. }\end{array}$ & $2,664.52$ & $3,044.35$ & $2,253.12$ & 257.88 & 249.25 \\
\hline \multirow[t]{2}{*}{8473} & $\begin{array}{l}\text { Prts \& Accssrs(Excl Covers, Carryng } \\
\text { Cases Etc)Usd Wth Mchns Of Hdg } \\
\text { No.8469 To } 8472\end{array}$ & $1,376.49$ & $1,354.83$ & $1,311.86$ & 239.62 & 239.62 \\
\hline & Total & $17,992.26$ & $23,887.57$ & $29,404.89$ & $22,792.4$ & $18,175.27$ \\
\hline
\end{tabular}

Source: Ministry of Commerce and Industry, Government of India. 


\subsubsection{Barriers and policy initiatives for the electronics industry}

India has the potential to develop and manufacture electronics/IT hardware for the global market and increase its global share in the converging areas of information, communication, and entertainment. However, the removal of duty protection coupled with the relatively small domestic market with low purchasing power and the inward orientation of Indian manufacturers have resulted in the closure of a large number of local manufacturing units. The Information Technology Agreement (ITA-I) of the WTO, to which India is a signatory, in 2005-2006 obliged India to remove import duties on 217 tariff lines concerning a range of electronics components and products. Under the Early Harvest Scheme (EHS) of the IndiaThailand FTA, duties on some electronics products imported by India from Thailand also dropped significantly. This caused problems for final goods producers. For instance, customs duty on color television sets were reduced to $0 \%$ on 1 September 2006, but duties on a number of inputs for the production of color televisions remained as high as $12.5 \%$. Hence, to help domestic final good producers survive and compete, it has become necessary to reduce the duty on certain imported inputs. This inverted duty structure in the Indian electronic industry has been identified as a serious issue which needs an urgent review. Moreover, Indian trade is suffering from lack of promotion and direction. Some of the issues are highlighted below:

- Non-exemption from income tax of the electronics/IT hardware export industry.

- Hurdles in the smooth operation of electronics and IT units under the Export Oriented Schemes [Software Technology Parks (STP)/Electronic Hardware Technology Park (EHTP)] due to mandatory customs bonding.

- Delays in import, procurement, and production processes caused by a very bureaucratic procedure of issuing certificates (e.g., Import Certificate, Procurement Certificate, and Re-warehousing Certificate).

\subsubsection{Integrating Indian Electronic Industry}

India has been very active in bilateral and regional cooperation through FTAs or Comprehensive Economic Cooperation Agreement (CECA). For instance, the country signed a Framework Agreement for an FTA with Thailand in 2003 and a Comprehensive Economic Cooperation Agreement (CECA) with Singapore in 2004. The FTA with Thailand presently covers only trade in goods while the CECA with Singapore covers trade in goods and services as well as investment. Moreover, India has drastically slashed duties on many electronic goods and this is considered to have helped several East and Southeast Asian countries as it provided easier access to Indian market.

Economies like Taipei,China; Korea; Malaysia; and more recently, the PRC, have recorded much higher growth in electronics and IT hardware industry. These countries are exporting worldwide, accounting for $20 \%$ of global electronics and IT hardware production. The PRC has already emerged as the $3^{\text {rd }}$ largest manufacturer of electronics and IT hardware, after US and Japan. The Indian electronics sector is comprised of a few large companies, several SMEs, and a large number of micro and household enterprises. Most of the micro enterprises are in an unorganized sector, which supply small components to relatively bigger players. Nevertheless, benefits from the current structure of Indian electronics sector are expected to materialize once the complementarity between the multinational enterprises (MNEs) and the SMEs triggers the emergence of RPNs. 


\subsection{The Automobile and Auto-components Industry}

\subsubsection{Automobile Sector}

The Indian automobile industry, which is one of the world's fastest growing automotive industries, expanded at a compounded annual growth rate (CAGR) of approximately $17 \%$ in the past five years (Society of Indian Automobile Manufacturers 2008). It is now the world's eleventh-largest manufacturer of passenger cars, the fourth-largest manufacturer of commercial vehicles, and the second-largest manufacturer of two-wheelers, producing 13 times more cars than it did 20 years ago (World Bank 2005). India is now among the top 10 countries that have designed, developed, and mass produced their own cars.

The Indian automotive sector has a presence across all vehicle segments and key components. In terms of volume, two-wheelers dominate the sector, followed by passenger vehicles. Until the 1990s, the industry had few players and was protected from global competition. After the government removed the requirement for licensing in 1993, the arrival of global players has resulted in a highly competitive Indian automotive sector.

Automobile manufacturing units are located all over India. However, as noted by the Automotive Component Manufacturers Association of India (ACMA), they are concentrated in pockets such as Chennai and Bangalore in the south, Pune in the west, the National Capital Region (NCR), which includes New Delhi and its suburban districts, in the north, Jamshedpur and Kolkata in the east, and Pithampur in the central region. Following global trends, most auto suppliers are located close to the manufacturing locations of original equipment manufacturer (OEM), forming regional automotive clusters. The three main clusters are centred around Chennai, Pune, and Delhi.

In terms of market, the three major export destinations of Indian automobiles in 2009 were UK, Italy, and Germany. However, the level of India's exports of automobiles is still considered low and it mainly caters to Western economies, South Asia, and Africa (Table 6).

Table 6: Top 10 Export Destinations of Indian Automobiles, 2009

\begin{tabular}{|l|r|}
\hline \multicolumn{1}{|c|}{ Country Name } & \multicolumn{2}{c|}{$\begin{array}{c}\text { Value } \\
\text { (US\$ Million) }\end{array}$} \\
\hline United Kingdom & 414.70 \\
\hline Italy & 367.08 \\
\hline Germany & 343.11 \\
\hline Netherlands & 197.66 \\
\hline Sri Lanka & 141.06 \\
\hline Nigeria & 138.26 \\
\hline Bangladesh & 130.89 \\
\hline South Africa & 126.80 \\
\hline Algeria & 119.84 \\
\hline France & 117.36 \\
\hline
\end{tabular}

In terms of automobile segments, passenger cars outnumbered other categories when it comes to exports, as it posted a very strong growth in the past five years. However, the level of value of automobiles' export from India remained low (Figure 2). 
In 2009, India sourced most of automobile imports from the western automobile manufacturers (Table 7).

Similar to the export trend, automobile imports of India were mostly passenger cars in the past five years. In terms of value of import payments, this automobile segment has significantly overtaken other automotive products, especially in recent years. This indicates that total automobile trade (both exports and imports) in India is dominated by passenger cars while other segments have remained significantly low.

Figure 2: Export Trend of Automobiles from India, 2004-05 to 2009-10

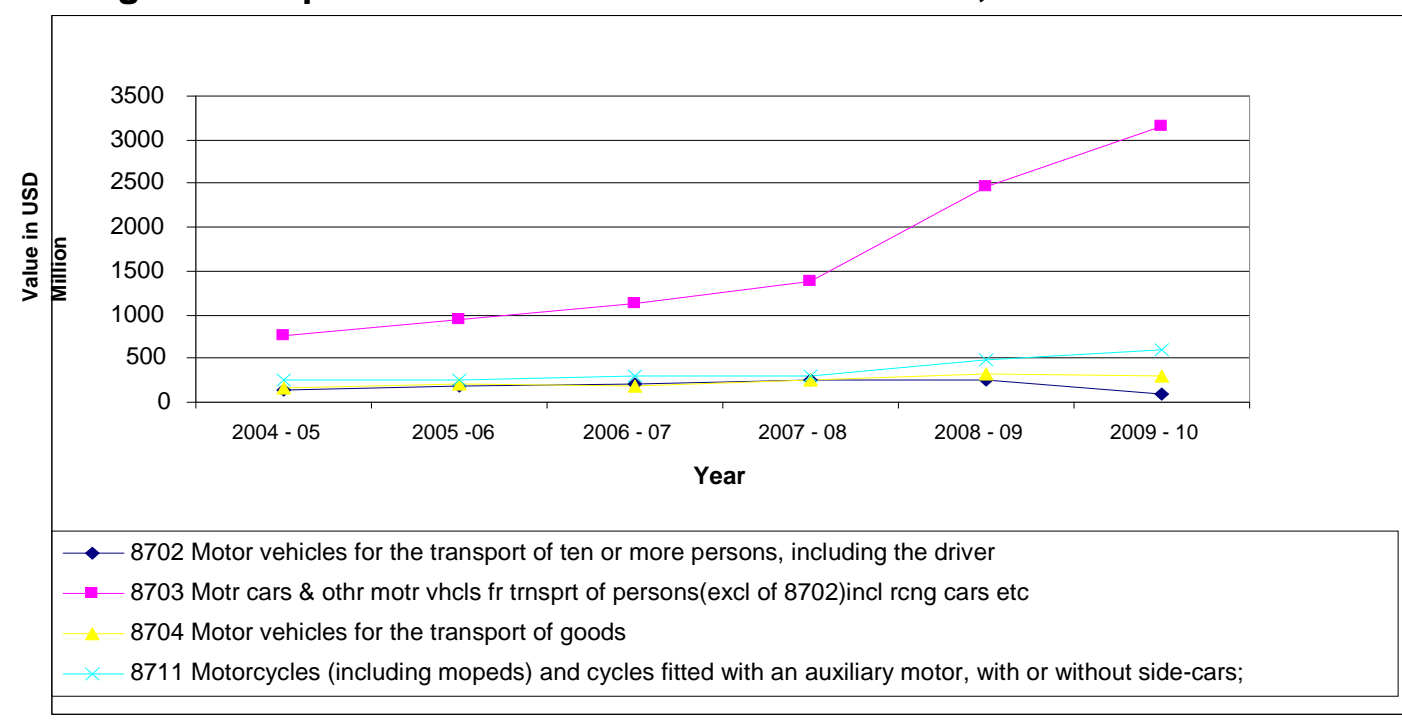

Source: Centre for Monitoring Indian Economy (CMIE), India Trades (Accessed 22 December 2011)

Table 7: Top 10 Sources of Indian Automobile Imports, 2009

\begin{tabular}{|l|r|}
\hline \multicolumn{1}{|c|}{ Country Name } & $\begin{array}{c}\text { Value } \\
\text { (US\$ Million) }\end{array}$ \\
\hline Germany & 163.20 \\
\hline Japan & 24.79 \\
\hline United States & 20.98 \\
\hline United Kingdom & 18.83 \\
\hline Slovak Republic & 13.24 \\
\hline Netherlands & 11.82 \\
\hline Korea & 10.07 \\
\hline PRC & 8.51 \\
\hline Thailand & 7.75 \\
\hline Sweden & 5.73 \\
\hline \multicolumn{2}{|l|}{ Source: WITS Accessed December 22, 2011) }
\end{tabular}


Figure 3: Import Trend of Automobiles in India, 2004-05 to 2009-10

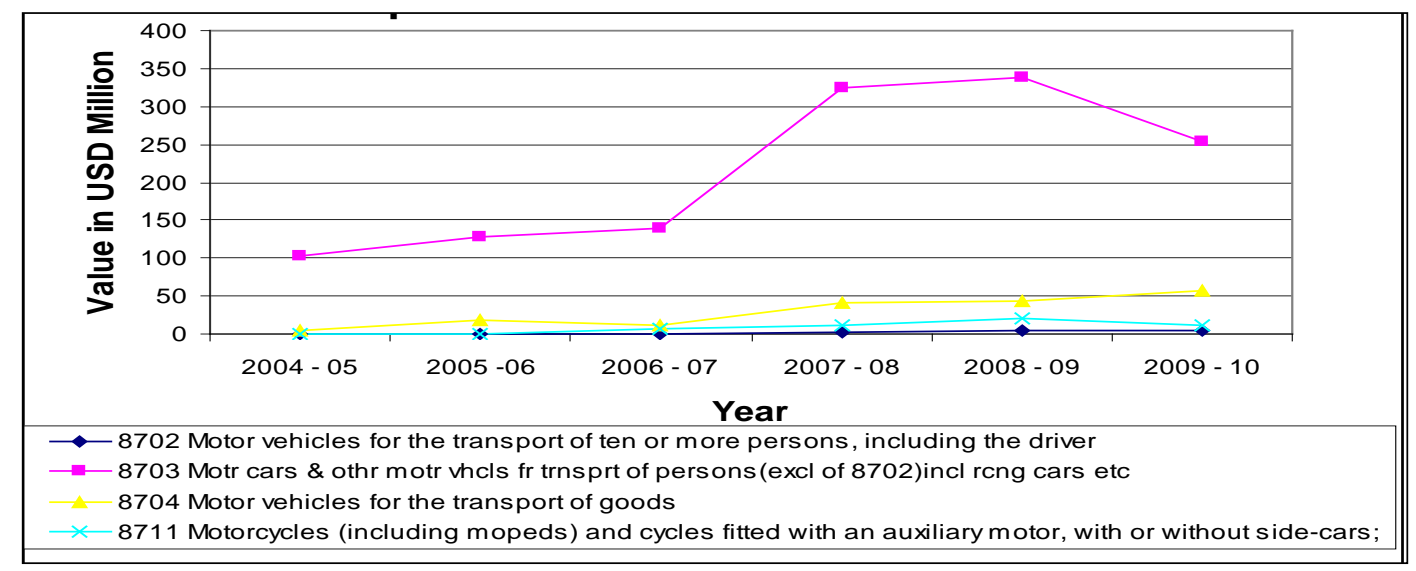

Source: Centre for Monitoring Indian Economy (CMIE), India Trades (Accessed December 22, 2011)

As previously discussed, from the mid-1990s onwards, the entry of a number of global players in the Indian automotive sector has caused a rapid transformation in the Indian market as it became increasingly competitive. Hyundai has emerged as the second-largest car manufacturer, after Maruti Udyog Ltd. ${ }^{5}$, in a very short period of time. The arrival of these MNCs also boosted the components sector, which advanced further with the liberalization of the investment and import regime. Hyundai set up a $100 \%$-owned subsidiary (the largest investment of the company outside Korea) in 1998. This initially brought in 14 Korean component suppliers to the Hyundai plant, since supplier of components was not originally available in Chennai. In total, Hyundai has about 70 major component suppliers, of which only 14 are Korean joint ventures (JV) and the rest are mainly Tamil Nadu-based firms. Suzuki also set up several JV suppliers around the Maruti factory in Gurgaon that provide advice on absorbing new technology and improving production efficiency.

Following the liberalization of policies and the high growth of domestic demand, several other MNCs, such as Toyota, Honda, and Ford, also entered the Indian market. A number of them have full production facilities while others still import major components and assemble them in India. As the import duties on used vehicles and new completely built units (CBU) remained very high ( $100 \%$ and $60 \%$, respectively), these companies found that setting up production facilities or importing cars in completely knocked down (CKD) form and having an assembly plant in India was more cost effective. Tariffs on components have declined considerably over the past few years. This has not only increased the production possibilities of cars but also fuelled international trade in components. Exports and imports of components have experienced somewhat similar growth patterns since 2000 (Nag, Banerjee, and Chatterjee 2007). The change of policy has infused new life into the component sector as many original equipment manufacturing (OEMs) are increasingly buying from domestic component manufacturers.

\subsubsection{Auto component Industry}

Component suppliers are the strength of the emerging automobile industry in India. The Indian automobile component sector is relatively labor-intensive by global standards and is

\footnotetext{
${ }^{5}$ Maruti was set up in collaboration with Suzuki. It remained as a joint venture company for a long time. Suzuki bought the Indian stakes converting Maruti into a wholly-owned subsidiary of Suzuki.
} 
in the transition stage as a low-cost base for exporting labor intensive products (Saripalle 2005). It is transforming itself from a low volume, fragmented market into an internationally competitive industry, building on the advantage of skill-oriented, labor-intensive components. Indian component suppliers have displayed a growing capability to cater to the engineering and production needs of some of the world's biggest car companies and many of the big car companies are now outsourcing several components from India. The manufacturing costs in India are 25-30\% lower than the Western counterparts. However, despite this growth, the share of Indian exports in the global auto component market is still considered to be very small. The dynamics of the industry are undergoing drastic restructuring and tiering. Various technological and non-technological innovations have been brought in by the industry to capitalize on the opportunities that are being created.

The Indian automotive component industry is highly fragmented. There are nearly 6,400 players in the sector, of which only about $6 \%$ is organized and the remaining $94 \%$ are smallscale, unorganized players (KPMG Report 2006). In terms of value-added, however, the organized players account for nearly $77 \%$ of the output in the sector. Recently, automotive production in India has increased significantly, rising from around US\$4,000 in 2000-01 to US\$26,000 million in 2010-11, although the estimated growth rate followed a fluctuating trend (Figure 4).

Figure 4: Auto Component Sector Production in India, 1996-97 to 2010-11

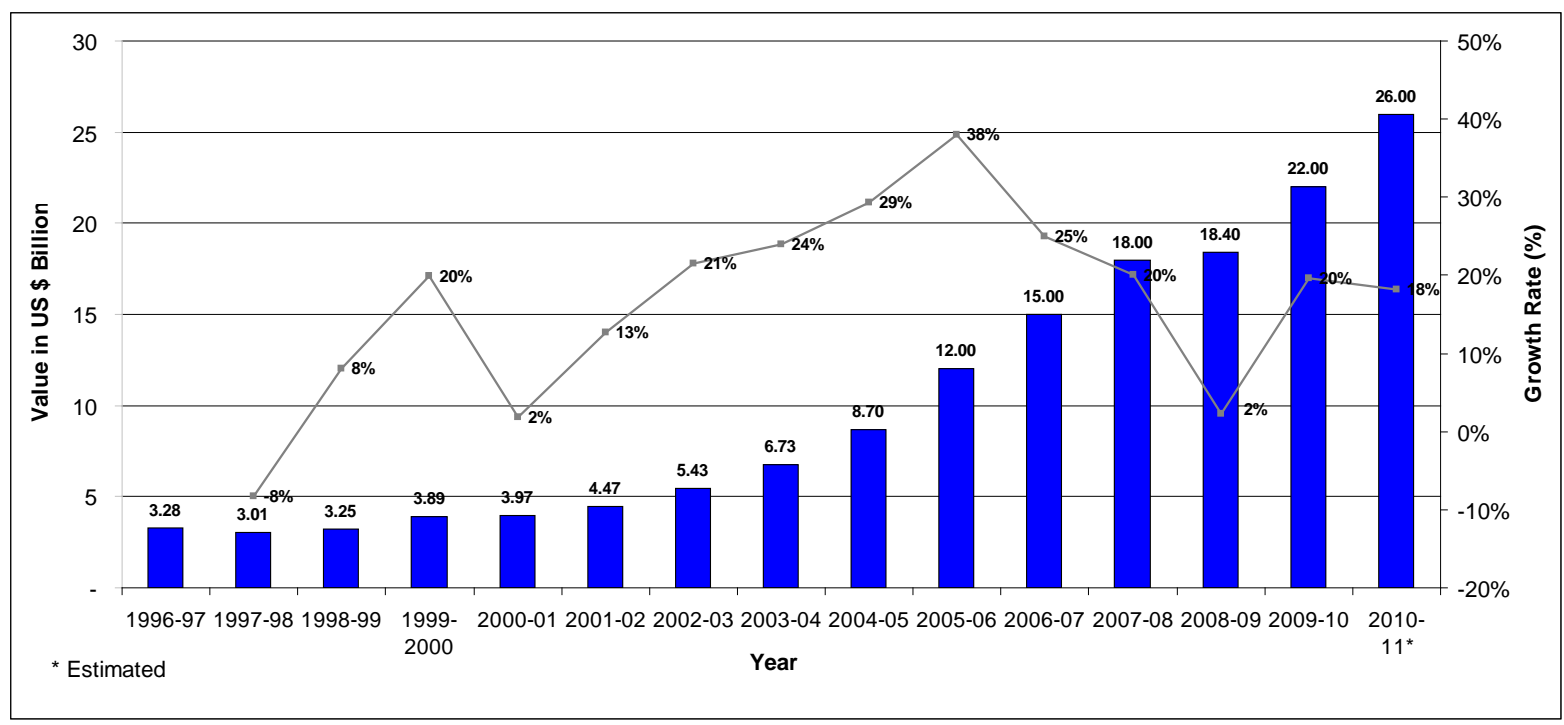

Source: Society of Indian Automobile Manufacturer's Association (SIAM) (Accessed 22 December 2011)

In terms of exports, the automotive components from India posted a sharp increase in the period 2002-2007. However, due to global recession, growth slowed from 2008 onwards. In 2009-10, total exports of auto component were around US\$3.8 billion. 
Figure 5: Auto Components Export of India, 1997-98 to 2009-10

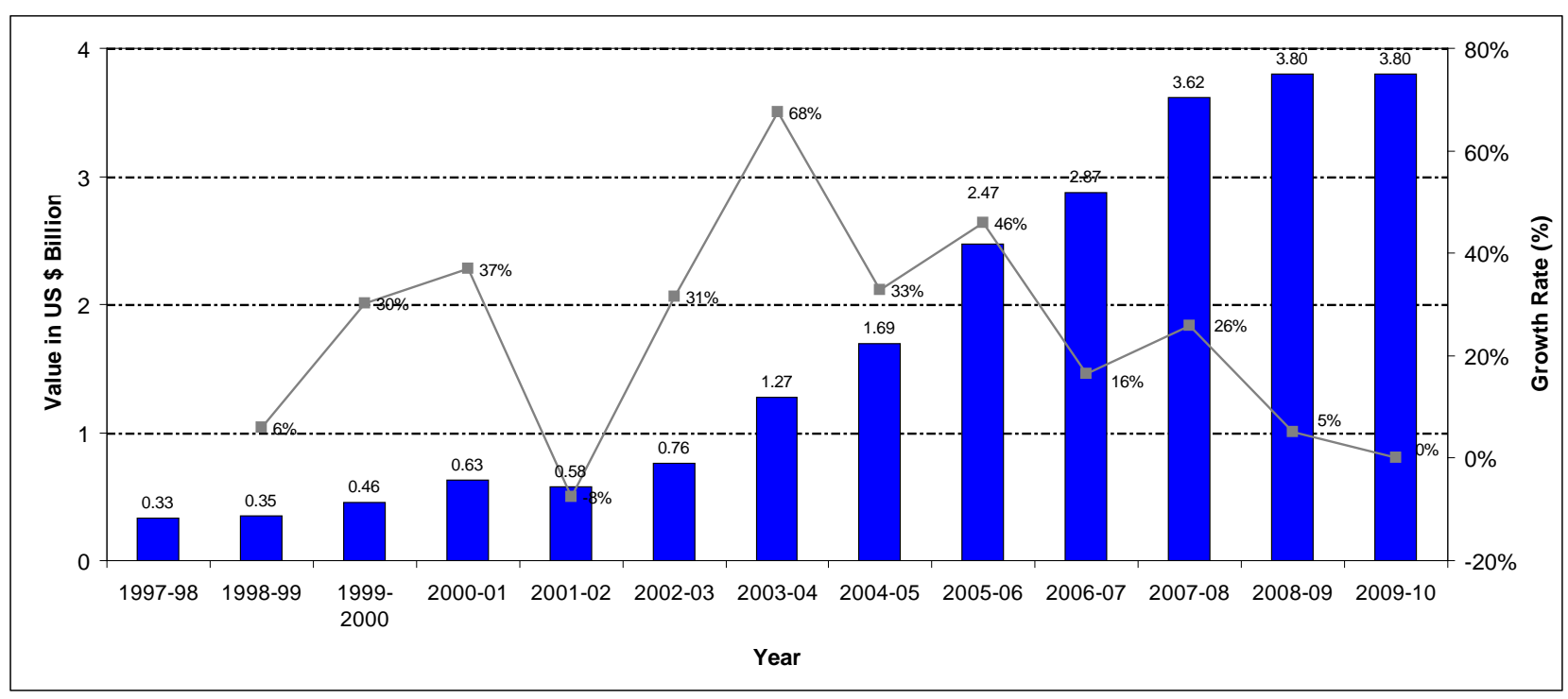

Source: SIAM (Accessed December 22, 2011)

\subsubsection{Barriers and Policy Initiatives}

The decline in tariff rates in automotive components has led to rapid growth of this sector. Demand for automotive components is driven in part by the drop in prices due to customs and excise cuts, and in part by excise cuts for automobiles. Other factors driving automotive component production are rapid income growth and the resulting expansion of demand. As per the earlier policy, OEMs had to increase the share of domestic inputs which led to the foundation of the component industry. Subsequently, the sector became quite confident in facing competition from abroad. The reforms of 1991 , followed by the entry of global OEMs and Tier-1 suppliers in India, paved the way for the expansion of a range of technologies and automotive component manufacturers. The vehicle manufacturers started outsourcing most of their components from automotive component manufacturers. With the de-licensing of the passenger car segment in 1993, the Indian auto industry has grown bigger with new international players entering the market. Since 2000, there have been many significant policy developments, such as the removal of Quantitative Restrictions on automobile imports and the decision to allow 100\% FDI in the sector. Financial liberalization meant easier access to credit for consumers and this resulted in an increase in car loans in India-a key driver of demand for automobiles. A cut in import tariffs on commercial vehicles increased competition in the Indian commercial vehicles (CVs) sector. As CVs are required in the development of infrastructure, the duty reduction on CVs may provide a boost to the improvement of India's infrastructure.

\subsubsection{Integration of the Auto Industry}

Much progress has been made towards the global integration of the Indian automobile industry. The bilateral and regional trade agreements were a significant step in achieving this, although the full benefits will not materialize until these agreements become fully operational. In case of the India-Thailand FTA, under the EHS, few auto components that 
had experienced a rapid increase in trade volume soon after the implementation of the agreement were included (e.g., gearboxes).

However, major stakeholders deem that Indian component manufacturers are still not in a position to compete with their counterparts in East Asia and Southeast Asia. As a result, some automotive components (such as engines) remain in the "negative list" in case of all forthcoming agreements with Asian countries. The industry has identified 77 items to be included in the negative list for all proposed bilateral and regional agreements India is currently negotiating with the region. Some key items proposed for the negative list are twowheelers with 75-cc to 250-cc engine capacity, petrol and diesel engines for all vehicles, and all commercial vehicles. Strict rules of origin (RoO) were also proposed and supported by the domestic industry.

A favorable initial industry environment and efficiency levels are necessary for reaping the benefits of RTA, or the result may only be a one-way trade. At present, the SMEs may not be in a position to integrate with the production network, which is mainly driven by MNCs. Moreover, SMEs require handholding in terms of dissemination of trade information, affordable technology, and easy financing.

With regard to a possible circular flow of final goods and components, India is linked more strongly with Western economies than with the economies of East Asia and Southeast Asia, from which the country is mainly importing.

Hence, there is still an apprehension about the inclusion of automotive components in RTAs with Asian countries. Technological collaboration and the capability to move up the value chain with innovative management skills are necessary requirements to enable an Indian auto component manufacturer to enter a production network.

\subsection{Parts and Components}

Through foreign trade and investment, East Asian economies have obtained technology and management know-how from foreign countries and these have contributed to economic growth of East Asian host countries by improving their production and technological capability. The composition of trade is shifting from low-skill products, such as textiles and garments, to higher-skill, higher technology products, especially machinery, which now accounts for over $40 \%$ of East Asia's exports and over $50 \%$ of intraregional exports. Among machinery exports, electronics and electrical products are the most substantial. The trend started in the electronics industry and subsequently spread into many other industries such as sport footwear, automobile and components, televisions and radio receivers, sewing machines, office equipment, electrical machinery, power and machine tools, cameras and watches, and printing and publishing machinery.

\subsubsection{Trade Scenario}

The export of $\mathrm{P} \& \mathrm{C}$ from India has been increasing gradually in the last five years, reaching around US\$51.8 billion in 2010. The major P\&C export item of India is power generating machinery. Other important machinery exported by India are professional scientific instruments and metal working general and specific machinery (Table 8). 
Table 8: Parts and Components Exports of India, 2005-2009

(Value in US\$ Million)

\begin{tabular}{|c|c|c|c|c|c|c|c|}
\hline HS & Commodity & 2005 & 2006 & 2007 & 2008 & 2009 & 2010 \\
\hline 71 & $\begin{array}{l}\text { Power generating } \\
\text { machinery }\end{array}$ & 15857.9 & 16091.55 & 19824.89 & 28466.39 & 29202.94 & 25253.98 \\
\hline 72 & $\begin{array}{ll}\text { Machinery for } \\
\text { particular } & \\
\text { industries } & \end{array}$ & 3813.4 & 5598.8 & 6557.83 & 7533.31 & 4516.13 & 5668.89 \\
\hline 73 & $\begin{array}{l}\text { Metal working } \\
\text { machinery }\end{array}$ & 2814.6 & 3403.8 & 5222.54 & 5782.65 & 4081.31 & 5307.19 \\
\hline 74 & $\begin{array}{l}\text { General industrial } \\
\text { machinery }\end{array}$ & 1520.73 & 3037.8 & 2917.12 & 1817.36 & 1802.59 & 5030.14 \\
\hline 75 & $\begin{array}{l}\text { automatic data } \\
\text { processing } \\
\text { machines }\end{array}$ & 21.22 & 27.53 & 27.21 & 24.67 & 23.44 & 24.22 \\
\hline 76 & $\begin{array}{l}\text { Telecommunicati } \\
\text { ons \& Sound } \\
\text { recording }\end{array}$ & 606.16 & 824.77 & 1124.13 & 1165.67 & 1040.56 & 1067.19 \\
\hline 78 & $\begin{array}{ll}\text { Road vehicles } \\
\text { parts }\end{array}$ & 17.38 & 27.58 & 55.47 & 29.17 & 117.53 & 79.7 \\
\hline 79 & $\begin{array}{l}\text { Transport } \\
\text { equipment }\end{array}$ & 45.16 & 722.39 & 305.62 & 406.97 & 407.12 & 532.43 \\
\hline 87 & $\begin{array}{l}\text { Professional } \\
\text { scientific } \\
\text { instruments }\end{array}$ & 3293.2 & 3766.12 & 4484.13 & 3.2392 & 6169.49 & 7578.18 \\
\hline 88 & $\begin{array}{l}\text { Photo and optical } \\
\text { goods }\end{array}$ & 63.05 & 77.54 & 693.28 & 1467.02 & 1030.34 & 1262.33 \\
\hline & Total & 28052.8 & 33577.88 & 41212.22 & 46696.45 & 48391.45 & 51804.25 \\
\hline
\end{tabular}

The bulk of imports of India are in telecommunications equipment. Trade in P\&C (both imports and exports) is quite significant in India, although it contributes only marginally to the country's total trade (Table 9).

Table 9: Automotive Parts and Components Imports of India, 2005-2009(Value in US\$ Million)

\begin{tabular}{|r|l|r|r|r|r|r|}
\hline $\begin{array}{c}\text { Product } \\
\text { Code }\end{array}$ & Product Description & $\mathbf{2 0 0 5}$ & $\mathbf{2 0 0 6}$ & $\mathbf{2 0 0 7}$ & $\mathbf{2 0 0 8}$ & $\mathbf{2 0 0 9}$ \\
\hline 71 & $\begin{array}{l}\text { Power generating } \\
\text { equipment }\end{array}$ & 1809.421 & 2112.099 & 3090.083 & 3958.847 & 3905.792 \\
\hline 72 & Industry special machine & 3795.48 & 5473.671 & 6911.69 & 8315.018 & 6778.965 \\
\hline 73 & Metalworking machinery & 1109.261 & 1859.606 & 2487.976 & 3450.669 & 2468.73 \\
\hline 74 & $\begin{array}{l}\text { Industrial equipment (not } \\
\text { elsewhere specified) }\end{array}$ & 3615.24 & 4880.488 & 6805.561 & 9176.707 & 7657.853 \\
\hline 75 & Office/dat proc machines & 3334.711 & 4152.871 & 4218.287 & 4481.422 & 4316.459 \\
\hline 76 & Telecomms etc equipment & 5754.427 & 7536.19 & 9920.038 & 7259.201 & 11633.85 \\
\hline 78 & Road vehicles & 996.0201 & 1276.217 & 1899.856 & 3185.88 & 2749.864 \\
\hline 79 & $\begin{array}{l}\text { Railway/tramway } \\
\text { equipment }\end{array}$ & 3950.671 & 8562.249 & 6101.146 & 17214.88 & 8705.509 \\
\hline 87 & Scientific/etc instrument & 1971.354 & 2334.578 & 3024.576 & 3671.198 & 3671.347 \\
\hline 88 & $\begin{array}{l}\text { Photographic } \\
\text { equipments/clocks }\end{array}$ & 484.0242 & 537.3898 & 640.0536 & 739.95 & 646.9617 \\
\hline & $\quad$ Total & $\mathbf{2 6 8 2 0 . 6 1}$ & $\mathbf{3 8 7 2 5 . 3 6}$ & $\mathbf{4 5 0 9 9 . 2 7}$ & $\mathbf{6 1 4 5 3 . 7 7}$ & $\mathbf{5 2 5 3 5 . 3 3}$ \\
\hline
\end{tabular}


The trade in $P \& C$ is somewhat triangular in nature. In $P \& C$, the developing economies of East Asia are becoming the factory of the world, assembling the P\&C supplied by developed and developing economies and selling the finished products to the world market. The structure of trade is triangular in nature-parts produced by Japan are exported to the PRC and the other Asian economies to be assembled as finished products, which are then exported to Europe, North America, or Japan. A range of mutually reinforcing factors have contributed to the rapid expansion of P\&C trade in Asia. Firstly, advances in production technology have enabled the industry to slice up the value chain into smaller components. Secondly, technological innovations in communication and transportation have contributed to significant reductions in the cost of service links involved in coordinating international operations. Thirdly, liberalization-related policy reforms (reductions in trade barriers) in both home and host countries have led to massive FDI in these economies. Lastly, high levels of intra-industry trade through RPNs helped the economies to be a part of the global value chain.

\subsubsection{Barriers and Policy Issues}

India has remained a small player in fragmentation-based international exchange and around $26 \%$ of its total trade is in P\&C. In recent years, increases in intra-regional trade in East Asia stem largely from fragmentation-based specialization. However, since the share of intra-regional trade to total trade of these countries has not increased, this only confirms that trade in Asia is largely dominated by trade in P\&C. While regionalism enhanced the growth of $\mathrm{P} \& \mathrm{C}$ trade in East and South East Asia, the maintained barriers against non-members (while allowing free trade among members) can be seen as a hindrance to the natural expansion of fragmentation-based specialization across countries, especially in South Asia.

Meanwhile, tariff barriers have come down to below $10 \%$ but it is not expected to go down further. As profit margins in volume-based $P \& C$ trade are very low, a reduction in tariff rates is considered desirable even if it is as small as $5-10 \%$.

As the PRC is heading towards overcapacity and its wage and non-wage costs are increasing, the absence of adequate intellectual property rights protection also plays an important role in an expected slowdown of investment in P\&C in the PRC. India could be seen as a natural next choice, but so far FDI in P\&C in India remains low. This is probably due to the presence of other small ASEAN members such as Viet Nam, which could be major competitors of India as they can take advantage of the ASEAN RPNs.

The P\&C trade is expected to continue to dominate Asian trade. The know-how and investments of MNCs and the aggressiveness and process efficiency of SMEs will provide a new dimension to $P \& C$ trade in the future. High labor productivity along with employment generation due to volume-based trade of standardized goods will ensure that the trend of $P \& C$ trade will remain stable in the coming years. Indian SMEs have shown a certain degree of resilience and hence Asian MNCs can assist them with funding and technology, which in turn may open possibilities in terms of product and process innovation.

\subsubsection{Integrating Parts and Components}

The formation of RTAs has simply resulted in substituting the existing tariff concessions, thereby generating new incentives for this trade. The regional economies have undertaken initiatives towards deeper trade and investment integration essentially for four reasons: 
- Defensive response to the proliferation of RTAs elsewhere;

- Dissatisfaction with the slow progress of trade and investment liberalization at the global and trans-regional levels;

- Need to improve international competitiveness through exploitation of scale economies; and

- Promotion of deeper regional integration and greater institution building.

One important issue regarding the proliferation of FTAs and economic partnership agreement (EPA) initiatives in East Asia-often dubbed the spaghetti bowl phenomenon-is how to ensure consistency across different regional trade arrangements. In particular, differing treatments of rules of origin can be quite counterproductive and the use of common tariff rates would be preferable. Another issue, common to any regional trade arrangement, is how to maintain WTO consistency, i.e., how to make the East Asian RTAs a building block for multilateral trade and FDI liberalization. ${ }^{6}$ Rules of origin in FTAs can be more binding for fragmentation trade compared with conventional final goods trade. Value-added at each stage of production is generally very small and therefore more sensitive to trade cost and delays arising from rules of origin compliance.

Currently, there are fears in South Asia that SMEs in ASEAN and the PRC could wipe out the South Asian P\&C sector. While many South Asian firms, especially from India, are now equipped to compete with their East Asian counterparts, South Asian countries are unable to enter into this value chain.

\subsection{The Future of the Asian Integration Process and the Role of India: 2030 Scenario}

Asian powers like the PRC and India are being envisaged as the drivers of the future global economy. However, Asia is quite diverse in terms of economic structure, political governance system, population distribution, and so forth. In the next two decades, ASEAN, India, and the PRC will be the engines of growth. However, growth alone is not sufficient to address poverty and inequality and hence, these countries require more prudent and direct domestic policies to handle this issue. In case of manufacturing industries, integration is foretold. The industries considered in this study will be at the forefront of this integration. India's "look east" policy is reflected in the number of FTAs and CECAs it has signed with Asian economies over the last few years. Looking at the time line of these FTAs, it is clear that most of the goods listed for concessions will be almost free by 2020 and countries will further liberalize the products in the negative/sensitive lists with the result that by 2030 most of the trade between ASEAN and India, especially in the goods sector, will attract zero tariffs. However, India and the PRC are now engaged only through APTA which moves slowly. Further initiatives supported by a political motivation seems to be important to bring these two giants agree for a deeper tariff cut. Nonetheless, trade between India and the PRC is rising exponentially.

Negotiation of non-tariff barriers (NTBs) among these countries are crucial for integration. So far the usage of FTA routes by traders has been relatively limited. Although, multiple RTAs/FTAs create confusion in terms of rules of origin or identifying best tariff discounts, NTBs and procedural hazards are the main obstacles to further RTA/FTA-led integration. Some efforts are already visible in streamlining the NTBS. ASEAN is already engaged in harmonizing NTBs across the region. India is considering the use of export and import policies to simplify some of the complex regulations. We expect that in the years ahead,

\footnotetext{
${ }^{6}$ Lloyd (2002) argued that bilateralism and FTAs are likely to result in greater multilateralism rather than work against it, but Brown, Deardorff, and Stern (2003) continued to believe in the desirability of a multilateralist approach.
} 
some kind of basic regulatory structures to manage exports and imports will be agreed upon. EU single market directives may provide useful pointers.

In terms of welfare gains from trade agreements between India and ASEAN, several studies have already been conducted. The studies suggest that ASEAN's overall welfare gains from this agreement will be higher than those expected for India, although India's gains will increase substantially if the country's large industries, which benefit from economies of scale can play an active role. India's major gains are expected in terms of "allocative efficiency" whereas ASEAN is expected to achieve significant gains from "terms of trade". This implies that ASEAN will be able to maintain export prices higher than those of India as demand for raw materials and inputs in production activity will be high (due to India's higher consumption and demand growth). On the other hand, India will benefit from more efficient production processes which will generate greater tax and other revenues for the government to spend on development programmes. India's gains in the ASEAN market will come mostly from smaller markets such as Viet Nam, Lao PDR, and Cambodia. Large Indian firms can also draw benefit from ASEAN markets if they focus more on 'economies of scale' and build their brands gradually (Nag and Sikdar 2011). The studies forecast that integration in P\&C and semi- finished goods will inevitably result from the agreement.

India has historically been more engaged with the Western economies than with Asia in the industries considered in this paper. Exports of Indian SMEs are mostly to Western countries. Indian SMEs have the ability to quickly move up the value chain as they tend to be good at product and process innovation. Also, good patent acts gives technology suppliers the confidence to work closely with Indian SMEs. However, these advantages are negated by India's appalling infrastructure, lack of modern logistics facilities, complicated layers of state and central regulation, and frequent delays in policy implementation-all factors that have crippled Indian SMEs. Moreover, the inability of Indian SMEs to raise funds is a major obstacle to business development and for them to take advantage of the opportunities provided by Asia's growing RPNs. Meanwhile, Asian companies still lack the confidence of doing business in India, which European and American companies have acquired over many years of being engaged with India.

In East Asia, the entire journey toward developing the regional production networks started with the "flying geese" model in which Japanese companies invested as joint venture (JV) partners in SMEs of those countries which increased both their technological and managerial efficiency and resulted in these companies becoming part of the international supply and value chain by default. On the contrary, in India, SMEs operate independently, possibly due to their capability to develop themselves with little outside help through financing and technology transfer. It is essential for a forum to be developed in which Asian SMEs can interact and bridge the gap, particularly in the identified sectors in this study. We expect that by 2030 , a new model, different from the "flying geese" pattern, will have become visible, with Indian companies having become integrated in the Asian RPN.

\section{Conclusion}

Since 1980s, an Asian production network was one of the major contributor toward the fast trade expansion and economic growth in East Asia. Developed Asian countries like Japan, Korea, and Singapore produces technology-intensive intermediate goods and capital goods and ships them to the People Republic of China (PRC) and ASEAN member countries for assembly by lower-skilled and low-cost workers. The finished products are then exported to advanced economies such as the US, Japan, Europe, and other countries. In view of ongoing global financial crisis that started in 2008 and European debt crisis and the slowdown in growth and recession in advanced economies, the ability of the rest of the world to absorb Asia's exports has decreased. Export production in some Asian countries has also 
been subsidized by artificially low prices for labor, land, and energy, and by lax enforcement of environmental regulations. Asian economies should thus rebalance away from relying too much on exporting subsidized goods to developed economies (Thorbeck and Bhattacharyay, 2012).

Asian economies need to rebalance their growth and depend more in intra-regional trade, cross-border investment and domestic consumption while reducing their high dependence on advanced economies as principal export markets. This calls for deepening, expanding and integrating Asian production network and reorienting export of final goods toward Asian Markets as well as markets of other emerging economies. This can be achieved by enhancing cooperation, integration and healthy competition as deeper trade linkages within the region present opportunities through complementary activities, product differentiation, and economies of scale.

In this regard, $\mathrm{ACl}$ needs to improve national and regional competitiveness and productivity to ensure self-reliance, higher employment, and sustenance and rebalancing of economic growth in these countries.

In the manufacturing sector, the region's potential can be maximized by expanding the East Asian regional production networks to further integrate regional trade, markets and economies, particularly with India, other low-income ASEAN countries, and South Asia. The region can also benefit by diversifying their products and markets within and outside the region and gearing their target market towards the rising $\mathrm{ACl}$ middle class. In addition, $\mathrm{ACl}$ needs to develop the service sector in key sectors (both tradables and nontradables such as education, financial services, health, ICT, infrastructure and logistics services, outsourcing and BPO, and tourism and hospitality) to increase internal value. With the increasing role of the service sector in the $\mathrm{ACl}$ economies, establishing or strengthening existing service production networks can deepen trade in services within and outside the region.

In 2014, the Indian Government has launched "Make in India" initiative. This initiative plans to enhance the domestic manufacturing industry and attract foreign investors to invest into the Indian economy. The manufacturing sector of India contributes around $15 \%$ to the national GDP. The objective of this initiate is to enhance this to a $25 \%$ contribution as seen with other developing nations of Asia. This initiative will assist in generating jobs, attracting increased foreign direct investment, and transform India into a manufacturing hub of the world. For the Make in India initiative, the government has identified 25 priority manufacturing sectors for promotion. These sectors include automotive and automotive components; and electrical machinery and electronic systems ${ }^{7}$. In order to implement this program successfully, India needs to be integrated significantly with Asian RPN.

The major conclusions of this study are as follows:

- In view of high competitiveness in providing outsourced information technology and $R \& D$ services in a wide range of industries, India has tremendous potential to integrate with RPN and become a key player like the PRC. India has to successfully attract FDI and enhance its manufacturing base. India should improve technological capability, hard and soft infrastructure and local support industries as well as promote efficient governance and regulatory system, including full transparency in the application of the law and thus enhance "Ease of Doing Business".

\footnotetext{
${ }^{7}$ http://www.mapsofindia.com/government-of-india/make-in-india.html
} 
- Integration in the manufacturing sector is inevitable, but the biggest challenge for this integration is the variety of NTBs across countries. So far the use of FTA routes by traders is relatively little. Multiple RTAs/FTAs create confusion in terms of rules of origin or identifying best tariff discounts. But NTBs and procedural hazards are the biggest stumbling blocks in the RTA/FTA-led integration. Another bottleneck is the poor infrastructure in ports, at border crossings, and complicated time consuming customs procedures.

- From the India-ASEAN FTA, India is expected to gain from the smaller ASEAN market while ASEAN will gain from India's rising demand for machineries and inputs. India's gain will increase substantially if it motivates its large industries with scale economies to play an active role in exploring ASEAN and PRC markets.

- In the sectors identified, historically, India is more engaged with the Western world. The advantage of Indian SMEs who are more linked to the developed Western world has never been explored fully by Asian countries. Indian SMEs have the ability to quickly move up the value chain through product and process innovation. Also, good patent act gives technology suppliers the confidence to work closely with Indian SMEs. However, Indian SMEs have been crippled by appalling infrastructure conditions, lack of modern logistics facilities, complex layers of state and central regulation, and delays in policy implementation, among others. The inability of Indian SMEs to raise funds also poses a big challenge for them, particularly in trying to develop their businesses and taking risks when linking up with the growing Asian RPN.

- It has been noticed that traditionally in the region (except India), service is linked with the manufacturing activity and hence, trade in transportation, and travel, and the like occupy significant position. However, the scenario has been changing and the demand for other services has been increasing sharply. The study finds that from the beginning, India has specialized or attempted to specialize in IT and professional services, whereas other major Asian players (Japan, the PRC, and Korea) have focused on traditional services around the manufacturing process, such as travel and transport services. Hence, India and these players including ASEAN complement each other.

- For service network, FTA seems to be a good route where countries find confidence to liberalize their services sector. Asian countries need to have discussion about service standards which can be linked with mutual recognition agreement (MRA) of certificates/qualification. Other than this, service integration in professional services is very difficult. Countries may identify top institutions in each service and encourage collaboration among them so that eventually, the mutual recognition becomes an easy step forward. For service integration among nations in the near future, the Asian academic institutions have significant role to play which these nations should not undermine.

Another important area which is not discussed in this paper but requires serious attention is the establishment and enhancement of the value chain or production network in agriculture. In view of the high food prices, food security is of great importance for the ACl and Asia as a whole. This network is expected to grow worldwide and the $\mathrm{ACl}$ region is no exception. Changing patterns of demand from cereals to horticultural products to packaged food provide new opportunities for agro companies. Moreover, the unleashing of rural demand in many countries of $\mathrm{ACl}$ is significant to attract more companies to reach them. Divergence of standards and its complexity in various countries will force companies to streamline their supply chain to have a special look into quality, warehousing and logistics. The emergence of large MNCs in the global food trade is also noteworthy. We expect that by 2030 there will only be a few regional big players that will be trading in the $\mathrm{ACl}$ region. The major problem 
will remain at the ground level, in terms of the possibility of farmers to comply with the changing standards and volume demanded by these players. The main reasons for this are the slow transmission of information, the lack of technology in farming, low productivity, and inability to connect with the global value chain, among others. India's Twelfth Five Year Plan (2012-2017) proposes higher levels of investments in agriculture, both by the public and private sectors to combat these problems.

A strong, efficient and integrated $\mathrm{ACl}$ production network can contribute to a balanced, sustainable, and resilient $\mathrm{ACl}$ and Asia which, in turn, can fuel the growth and prosperity and enhance the stability of Asian economies as well as the rest of the world. 


\section{References}

Ando, M. and F. Kimura. 2003. Fragmentation and Agglomeration Matter: Japanese Multinationals in America and East Asia. North American Journal of Economics and Finance 14 (3): 287-317.

Athukorala, P., and N. Yamashita. 2006. Product Fragmentation Trade Integration: East Asia in Global Context. North American Journal of Economics and Finance 17: 233-56.

Baldwin, R.E. 2007. Managing the Noodle Bowl: The Fragility of East Asian Regionalism. Working Paper Series on Regional Economic Integration. No. 7. Manila: Asian Development Bank (ADB).

De, D. 2011. Regional trade and international production networks: The context of automobile industry in Asia. International Journal of Technology Management and Sustainable Development 10: 1, 77-95.

Enterprise Information Management. 2012. Available: http://www.opentext.com (accessed 12 January 2012).

Ernst, D., and L. Kim. 2002. Global Production Networks, Knowledge Diffusion, and Local Capability Formation. Research Policy 31 (2002): 417-29.

Fernandez-Stark, K., P. Bamber, and G. Gereffi. 2010. Chile's Offshore Services Value Chain. Center on Globalization, Governance \& Competitiveness, Duke University. http://www.cggc.duke.edu/pdfs/CGGC-

CORFO Chiles Offshore Services Value Chain March 1 2010.pdf

Gereffi, G. 1994. The Organisation of Buyer-Driven Global Commodity Chains: How U.S. Retailers Shape Overseas Production Networks. In: Commodity Chains and Global Capitalism, edited by G. Gereffi and M. Korzeniewicz. Westport, CT: Praeger.

Gereffi, G. 1999. International Trade and Industrial Upgrading in the Apparel Commodity Chain. Journal of International Economics 48(1) : 37-70.

Government of India. 2012. Economic Survey 2010-11.

Japan Bank for International Cooperation (JBIC). 2010. Survey Report on Overseas Business Operations by Japanese Manufacturing Companies. Tokyo: JBIC.http://www.jbic.go.jp/en/about/press/2010/1203-01/eibunn_120224.pdf

Kimura, F., and M. Ando. 2004. The economic analysis of international production/distribution networks in East Asia and Latin America: The implication of regional trade arrangements. Business and Politics 7(1).

Kojima, K. 2000. The 'flying geese' model of Asian economic development: origin, theoretical extensions, and regional policy implications. Journal of Asian Economics 11: 375-401

KPMG Report. 2006. Automotive: A Report by KPMG for IBEF.

Kumar, N. 2007. Regional Economic Integration, Foreign Direct Investment and EfficiencySeeking Industrial Restructuring in Asia: The Case of India. RIS Discussion Paper No. 123. New Delhi: Research and Information System for Developing Countries (RIS). 
Machikita, T., and Y. Ueki. 2010. Spatial Architecture of the Production Networks in Southeast Asia. Papers DP-2010-01. Economic Research Institute for ASEAN and East Asia.

Maurer. A., and F. T. Tschang. 2011. An Exploratory Framework for Measuring Services Value-added. Paper presented at the PECC-ADBI Conference "Services Trade: New Approaches for the 21st Century" held in Hong Kong, China on 1-3 June 2011.

Mikic M. 2011. Fighting Irrelevance: The Role of Regional Trade Agreements in International Production Networks in Asia-ARTNet. UNESCAP.

Ministry of Commerce \& Industry, various years, Government of India.

Nag B., and D. De. 2008. Integration of small and medium-sized Enterprises in International Production Networks: The automotive industry in Asia. Published in Macao Regional Knowledge Hub. Working Papers No. 12. December 2008.

Nag B. 2011. Trade liberalization and international production networks: Experience of the Indian automotive sector. In: Fighting Irrelevance: The Role of Regional Trade Agreements in International Production Networks in Asia. ESCAP, United Nations, New York.

Nag B., and D. De. 2011. Rules of Origin and development of regional production network in Asia: Case Studies of Selected Industries. Asia-Pacific Research and Training Network on Trade. Working Paper Series. No. 101. May 2011.

Nag, B., and C. Sikdar. 2011. Welfare Implication of India-ASEAN FTA: An Analysis using GTAP Model, IIFT Working Paper EC-11-06, http://cc.iift.ac.in/research/Docs/WP/06.pdf

Nag, B., S. Banerjee, and R. Chatterjee. 2007. Changing Features of the Automobile Industry in Asia: Comparison of Production, Trade and Market Structure in Selected countries. Asia-Pacific Research and Training Network on Trade, Working Paper Series. No. 37.

$\begin{array}{lll}\text { Planning } & \text { Commission } & \text { India, }\end{array}$ http://planningcommission.nic.in/plans/planrel/12appdrft/appraoch 12plan.pdf (Accessed 12 January 2012).

Rajan, R., and R. Sen. 2002. A Decade of Trade Reforms in India: How It Compares with East Asia. World Economics 3 (4): 1-14.

SIAM. 2008: http://www.siamindia.com/scripts/industrystatistics.aspx

The Times of India, 2012 http://articles.timesofindia.indiatimes.com/2011-1012/india/30270780 1 food-security-bill-food-insecurity-world-food-system Accessed 12 January.

Thorbeck, W., and Bhattacharyay, B. 2012. Role of Production Networks in Sustaining and Rebalancing Asia's Growth, CESifo Working Paper No. 3896, July.

Thorbeck, W., and Salike, N. 2011, Understanding Foreign Direct Investment in East Asia, ADB Institute Working Paper, June, No. 210.

UNESCAP. 2011. Asia Pacific Trade \& Investment Report. 
UNESCAP. 2011. Trade and Investment Division. Fighting Irrelevance: The Role of Regional Trade Agreements in International Production Networks in Asia.

Urata, S., and H. Kawai. 2002. Technological Progress by Small and Medium Enterprises in Japan. Small Business Economics 18(1-3): 53-67.

World Bank. 2005. Global Economic Prospects: Trade, Regionalism, and Development. Washington, DC: World Bank.

World Integrated Trade Solutions, World Bank. available : http://wits.worldbank.org/wits/

WTO. 2011. World Trade Report 2011: WTO and preferential trade agreements: From coexistence to coherence. Geneva, WTO. . 